\title{
Source apportionment of black carbon aerosols from light absorption observation and source-oriented modeling: an implication in a coastal city in China
}

\author{
Junjun Deng ${ }^{1}$, Hao Guo ${ }^{2}$, Hongliang Zhang ${ }^{3}$, Jialei Zhu ${ }^{1}$, Xin Wang ${ }^{1}$, and Pingqing Fu ${ }^{1}$ \\ ${ }^{1}$ Institute of Surface-Earth System Science, School of Earth System Science, Tianjin University, Tianjin 300072, China \\ ${ }^{2}$ Department of Earth System Science, University of California Irvine, CA 92697-3100, USA \\ ${ }^{3}$ Department of Environmental Science and Engineering, Fudan University, Shanghai 200438, China
}

Correspondence: Junjun Deng (dengjunjun@tju.edu.cn) and Hongliang Zhang (zhanghl@ fudan.edu.cn)

Received: 8 May 2020 - Discussion started: 8 June 2020

Revised: 17 October 2020 - Accepted: 19 October 2020 - Published: 27 November 2020

\begin{abstract}
Black carbon (BC) is the most important lightabsorbing aerosol in the atmosphere. However, sources of atmospheric BC aerosols are largely uncertain, making it difficult to assess its influence on radiative forcing and climate change. In this study, year-round light-absorption observations were conducted during 2014 using an aethalometer in Xiamen, a coastal city in Southeast China. Source apportionment of $\mathrm{BC}$ was performed and temporal variations in $\mathrm{BC}$ sources were characterized based on both light absorption measurements and a source-oriented air quality model. The annual average concentrations of $\mathrm{BC}$ from fossil fuel $\left(\mathrm{BC}_{\mathrm{ff}}\right)$ and biomass burning $\left(\mathrm{BC}_{\mathrm{bb}}\right)$ by the aethalometer method were $2932 \pm 1444 \mathrm{ng} \mathrm{m}^{-3}$ and $1340 \pm 542 \mathrm{ng} \mathrm{m}^{-3}$, contributing $66.7 \%$ and $33.3 \%$ to total $\mathrm{BC}$, respectively. A sensitivity analysis was performed with different absorption Ångström exponent (AAE) values of fossil fuel combustion $\left(\alpha_{\mathrm{ff}}\right)$ and biomass burning $\left(\alpha_{\mathrm{bb}}\right)$, suggesting that the aethalometer method was more sensitive to changes in $\alpha_{\mathrm{bb}}$ than $\alpha_{\mathrm{ff}} . \mathrm{BC}_{\mathrm{bb}}$ contribution exhibited a clear diurnal cycle, with the highest level $(37.9 \%)$ in the evening rush hour and a seasonal pattern with the maximum $(39.9 \%)$ in winter. Conditional probability function (CPF) analysis revealed the large biomass-burning contributions were accompanied by east-northeasterly and northerly winds. Backward trajectory indicated that air masses from North and EastCentral China were associated with larger biomass-burning contributions. Potential source contribution function (PSCF) and concentration-weighted trajectory (CWT) suggested that North and East-Central China and Southeast Asia were po-
\end{abstract}

tential sources of both $\mathrm{BC}_{\mathrm{ff}}$ and $\mathrm{BC}_{\mathrm{bb}}$. The source-oriented modeling results showed that transportation, residential and open biomass burning accounting for $45.3 \%, 30.1 \%$ and $17.6 \%$ were the major BC sources. Among the three fuel catalogs, liquid fossil fuel (46.5\%) was the largest source, followed by biomass burning $(32.6 \%)$ and coal combustion $(20.9 \%)$. Source contributions of fossil fuel combustion and biomass burning identified by the source-oriented model were $67.4 \%$ and $32.6 \%$, respectively, close to those obtained by the aethalometer method. The findings provide solid support for controlling fossil fuel sources to limit the impacts of $\mathrm{BC}$ on climate change and environmental degradation in the relatively clean region in China.

\section{Introduction}

Black carbon (BC) aerosol is a vital air pollutant throughout the surface earth system and has attracted great concern regarding its multiple impacts on human health, climate change and atmospheric visibility (Bond et al., 2013; Zhuang et al., 2018, 2019; Chen et al., 2020). As the most important light-absorbing component of $\mathrm{PM}_{2.5}$ (particulate matters with aerodynamic diameter less than $2.5 \mu \mathrm{m}$ ), BC exerts a key and unique role in the climate system by absorbing solar radiation, affecting chemical/physical properties of cloud and influencing snow and ice cover (Jacobson, 2002; Ramanathan and Carmichael, 2008; Bond et al., 2013; Qian et al., 2014; Kim et al., 2015). BC is even found as the second 
most important climate-warming agent after carbon dioxide, with a positive climate forcing of $1.1 \mathrm{~W} \mathrm{~m}^{-2}$, greater than that of methane (Bond et al., 2013). BC also has impacts on urban weather conditions and may play a key role in extreme weather (Ding et al., 2013; Fan et al., 2015; Saide et al., 2015; Wang et al., 2018). Under polluted environments, BC has significant influence on pollution development (Ding et al., 2016; Peng et al., 2016; Lou et al., 2019). In addition, BC leads to visibility impairment because of its strong absorption of visible light (Watson, 2002) and has adverse impacts on human health due to its adsorption captivity (Janssen et al., 2011; Colicino et al., 2017). Nevertheless, due to lacking observational constraints and uncertainties in emission inventories, large uncertainties still exist in $\mathrm{BC}$ emissions including absolute fluxes and relative source contributions of fossil versus biomass combustion, which will complicate our knowledge on the multiple BC effects. It is also necessary to clarify the contributions of different sources to BC in order to determine efficient emission mitigation strategies. At global scale, BC emission sources can be attributed to fossil fuels $(\sim 40 \%)$, open biomass burning $(\sim 40 \%)$ and biofuels ( $\sim 20 \%$ ) (Ramanathan and Carmichael, 2008). However, these fractions vary significantly because of the substantial spatial and temporal variations in BC emissions (Venkataraman et al., 2005; Rehman et al., 2011; Cheng et al., 2013; Andersson et al., 2015).

Several source apportionments for quantitatively differentiating between biomass and fossil sources of ambient BC aerosol have been conducted using observation-based methods, such as the isotope (e.g., radiocarbon) analysis technique and light-absorbing property analysis (Sandradewi et al., 2008; Gustafsson et al., 2009; Liu et al., 2014; Vaishya et al., 2017; Helin et al., 2018; Kalogridis et al., 2018; Mousavi et al., 2018; Jing et al., 2019; Kant et al., 2020). For example, Andersson et al. (2015) presented dual carbon isotope constrained $\mathrm{BC}$ source apportionment in three key hotspot regions in China during a severe haze event, finding that biomass burning contributed $\sim 30 \%$ to $\mathrm{BC}$, whereas fossil fuel sources were dramatically different between north and south. The aethalometer model was adopted to analyze light absorption at multi-wavelengths to assess the fossil fuel and biomass combustion contributions to BC in Delhi, revealing that the contribution of biomass burning was $28 \%$ on average (Dumka et al., 2018). Mousavi et al. (2019) apportioned BC in the Milan metropolitan area to the fossil fuel and biomass-burning emission using the aethalometer model with the absorption Ångström exponent (AAE) values derived from the ${ }^{14} \mathrm{C}$ radiocarbon analysis, highlighting the significant impact of residential wood burning on BC. Such observation-based source apportionment methods are powerful to understand the $\mathrm{BC}$ sources at given receptor locations. However, the methods are highly dependent on accurate observations with high temporal resolution, which is unavailable for most regions without the measurement instruments. For example, the isotope method, especially the
${ }^{14} \mathrm{C}$ analysis, is costly and lacks high temporal resolution. Therefore, although many observation-based BC source apportionments have been carried out, the source-based method can still be a strong supplement. For example, Winiger et al. (2019) conducted observation-based source apportionment of circum-Arctic BC with carbon isotope analysis and found that comparison of Lagrangian atmospheric transport model (FLEXPART-ECLIPSE-GFED) predictions with the observations agreed well with each other for BC concentrations, with larger discrepancies for (fossil/biomass-burning) sources, indicating the misallocations of emissions in the emission inventories.

Source-oriented modeling, which estimates pollution levels and identifies sources using chemical transport models (CTMs) with the inputs of emission inventory and meteorology, is another useful tool to study potential factors deriving BC. Such a source apportionment technique has been developed and used for direct source apportionment of PM in more than a decade (Kleeman et al., 2007; Ying et al., 2008; Zhang et al., 2014). For example, Hu et al. (2015) found that residential emission was the major contributor to $\mathrm{BC}$ in spring and winter, while industrial emission was important in summer and fall in China. Guo et al. (2017) quantified the contributions of different sources in northern India and found that industry was the largest source of BC. Although the source-oriented modeling is powerful, limitations exist, such as the inability to take into account unknown sources and the imprecise information on emission inventories and meteorology. The method is highly dependent on accuracy of emission inventory, which is unfortunately an enormous challenge. A pollution source not in the emission inventory will not emerge as a contributor to the CTM results. Taking into account the advantages and disadvantages of the observation- and modeling-based methods, a combination of the two methods can be a complement to each other for providing reliable and reasonable information on pollution sources and contributions.

China is the largest source of BC aerosols in the world (Wang et al., 2012; Bond et al., 2013; Huang et al., 2016); remarkable influences of $\mathrm{BC}$ on air quality, weather condition and climate change were revealed in China (Menon et al., 2002; Ding et al., 2016; Huang et al., 2016; Yang et al., 2017). Spatiotemporal distributions and regional transport mechanisms of BC in China as well as their affecting factors have been widely investigated with field measurements or model simulations (Cao et al., 2010; Wu et al., 2013; Wang et al., 2015; Zhang et al., 2019; Zheng et al., 2019; Deng et al., 2020). In contrast, source apportionment studies on BC aerosols in China are still limited and mostly distributed in heavily polluted areas (Chen et al., 2013; Andersson et al., 2015; K. Li et al., 2016; N. Li et al., 2016; Yu et al., 2018; Jing et al., 2019). In this study, the observation-based method was combined with the source-oriented modeling to quantify the contributions of different sources of BC in a relatively clean region in China. The results of the two source appor- 


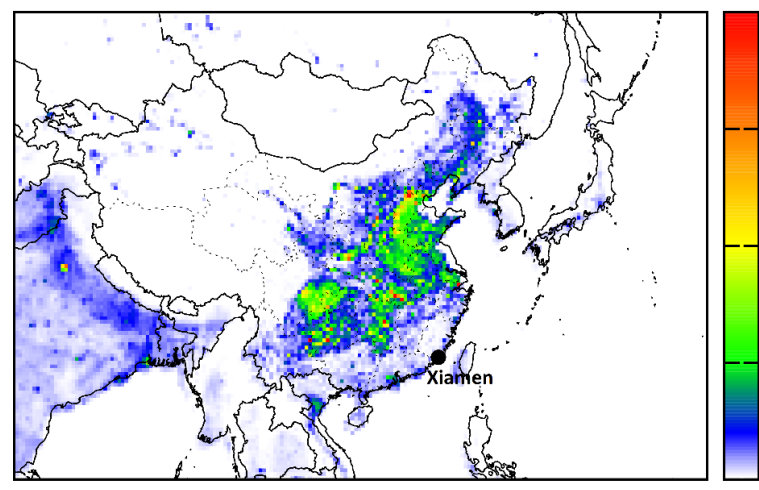

200

150

100

50

Figure 1. Location of Xiamen, China, with spatial distribution of annual average $\mathrm{BC}$ emission rate $\left(\mathrm{g} \mathrm{s}^{-1}\right)$. $\mathrm{BC}$ emission data in China are from the MEIC inventory developed by Tsinghua University.

tionment methods were inter-compared. Temporal variability, potential sources and transport pathways of BC from fossil fuel and biomass burning were also characterized. The findings help better understand the main sources and relative contributions of $\mathrm{BC}$ and provide valuable information to adopt effective emission reduction measures to control BC pollution in not heavily polluted regions.

\section{Methodologies}

\subsection{Observation site and measurements}

The field campaign was performed in the Institute of Urban Environment, Chinese Academy of Sciences (118 03'E, $24^{\circ} 36^{\prime} \mathrm{N}$ ) in the coastal city of Xiamen in China (Deng et al., 2016, 2020). Xiamen is located in the western Taiwan Strait region, which is adjacent to the Yangtze River Delta region (YRD) and the Pearl River Delta region (PRD) (Fig. 1). Xiamen has a small local emission of BC (Fig. 1) and a better diffusion condition compared to some developed cities in East China, which might lead to a lower BC concentration in Xiamen (Deng et al., 2020). However, Xiamen is often affected by emissions from polluted areas by long-range transport under the influence of the East Asia monsoon (Deng et al., 2020). Therefore, conducting source apportionment of $\mathrm{BC}$ over Xiamen is very representative for improving our understanding of the sources of $\mathrm{BC}$ and their transport characteristics in a relatively clean region.

The observation site ( $10 \mathrm{~m}$ above sea level) lies approximately $15 \mathrm{~km}$ away from the downtown to the southeast. None of the large industrial sources was within $10 \mathrm{~km}$ away, and there were only a few construction and traffic sources. The measurement instruments were arranged on the rooftop ( $8 \mathrm{~m}$ above ground level) of the site. Real-time measurements of $\mathrm{BC}$ mass concentration were conducted with a seven-wavelength $(370,470,520,590,660,880$ and $950 \mathrm{~nm}$ ) aethalometer (AE31, Magee Scientific) in January-
December 2014. An aethalometer with a $\mathrm{PM}_{2.5}$ cut-off inlet worked at a flow rate of $5 \mathrm{~L} \mathrm{~min}^{-1}$ and estimated light attenuation under the principle of optical transmission (Hansen et al., 1984). BC concentration was then calculated according to the light attenuation. The concentration measured at $880 \mathrm{~nm}$ is considered to be the standard value of atmospheric $\mathrm{BC}$ because $\mathrm{BC}$ is the predominant light-absorbing species at this wavelength, with little impact from other compounds (Ganguly et al., 2005). The method reported in Virkkula et al. (2007) was applied to correct BC mass concentration due to shadowing effects and multiple scattering effects.

\subsection{Observation-based source apportionment}

Observation-based source apportionment of BC in Xiamen was performed with the aethalometer method. The method based on the two-component assumption has been widely adopted to assess the contribution from fossil fuel combustion and biomass burning (Sandradewi et al., 2008; Favez et al., 2010; Liu et al., 2014; Rajesh and Ramachandran, 2017; Martinsson et al., 2017; Dumka et al., 2018; Helin et al., 2018; Mousavi et al., 2019; Mbengue et al., 2020). The aethalometer method apportions the total $\mathrm{BC}$ to $\mathrm{BC}_{\mathrm{ff}}(\mathrm{BC}$ emitted by fossil fuels) and $\mathrm{BC}_{\mathrm{bb}}$ ( $\mathrm{BC}$ emitted by biomass burning) contributions. $\mathrm{BC}_{\mathrm{ff}}$ and $\mathrm{BC}_{\mathrm{bb}}$ are expressed as follows:

$\mathrm{BC}_{\mathrm{ff}}=\mathrm{BC} \times \frac{b_{\mathrm{abs}, \mathrm{ff}}(\lambda)}{b_{\mathrm{abs}}(\lambda)}$,
$\mathrm{BC}_{\mathrm{bb}}=\mathrm{BC} \times \frac{b_{\mathrm{abs}, \mathrm{bb}}(\lambda)}{b_{\mathrm{abs}}(\lambda)}$,

where $b_{\text {abs }}(\lambda)$ is light absorption at a wavelength of $\lambda$, and $b_{\text {abs,ff }}$ and $b_{\text {abs,bb }}$ are light absorption coefficients for fossil fuel and biomass burning, respectively. The light absorption depends on the wavelength, satisfying the following relation:

$\frac{b_{\mathrm{abs}}\left(\lambda_{1}\right)}{b_{\mathrm{abs}}\left(\lambda_{2}\right)}=\left(\frac{\lambda_{1}}{\lambda_{2}}\right)^{-\alpha}$,

where $\alpha$ is the AAE value. $b_{\text {abs }}$ is assumed to apportion to $b_{\text {abs,ff }}$ and $b_{\text {abs,bb }}$ contributions in the two-component method (Sandradewi et al., 2008):

$b_{\mathrm{abs}}(\lambda)=b_{\mathrm{abs}, \mathrm{ff}}(\lambda)+b_{\mathrm{abs}, \mathrm{bb}}(\lambda)$.

Using Eqs. (3)-(4) and $b_{\text {abs }}$ measured at two different wavelengths, the fossil fuel and biomass-burning contribution can be derived using the following equations: 
$\frac{b_{\mathrm{abs}, \mathrm{ff}}\left(\lambda_{1}\right)}{b_{\mathrm{abs}, \mathrm{ff}}\left(\lambda_{2}\right)}=\left(\frac{\lambda_{1}}{\lambda_{2}}\right)^{-\alpha_{\mathrm{ff}}}$,

$\frac{b_{\mathrm{abs}, \mathrm{bb}}\left(\lambda_{1}\right)}{b_{\mathrm{abs}, \mathrm{bb}}\left(\lambda_{2}\right)}=\left(\frac{\lambda_{1}}{\lambda_{2}}\right)^{-\alpha_{\mathrm{bb}}}$,

$b_{\mathrm{abs}, \mathrm{bb}}=\frac{b_{\mathrm{abs}}\left(\lambda_{1}\right)-b_{\mathrm{abs}}\left(\lambda_{2}\right) \cdot\left(\frac{\lambda_{1}}{\lambda_{2}}\right)^{-\alpha_{\mathrm{ff}}}}{\left(\frac{\lambda_{1}}{\lambda_{2}}\right)^{-\alpha_{\mathrm{bb}}}-\left(\frac{\lambda_{1}}{\lambda_{2}}\right)^{-\alpha_{\mathrm{ff}}}}$,

$b_{\mathrm{abs}, \mathrm{ff}}=\frac{b_{\mathrm{abs}}\left(\lambda_{1}\right)-b_{\mathrm{abs}}\left(\lambda_{2}\right) \cdot\left(\frac{\lambda_{1}}{\lambda_{2}}\right)^{-\alpha_{\mathrm{bb}}}}{\left(\frac{\lambda_{1}}{\lambda_{2}}\right)^{-\alpha_{\mathrm{ff}}}-\left(\frac{\lambda_{1}}{\lambda_{2}}\right)^{-\alpha_{\mathrm{bb}}}}$,

where $\alpha_{\mathrm{ff}}$ and $\alpha_{\mathrm{bb}}$ are the AAE values for fossil fuel and biomass burning, respectively. For preselected $\alpha_{\mathrm{ff}}$ and $\alpha_{\mathrm{bb}}$ values, $b_{\mathrm{abs}, \mathrm{ff}}$ and $b_{\mathrm{abs}}$ bb can be calculated by Eqs. (7)-(8). $\mathrm{BC}_{\mathrm{ff}}$ and $\mathrm{BC}_{\mathrm{bb}}$ can be obtained by combining all the above equations and assumed values for $\alpha_{\mathrm{ff}}$ and $\alpha_{\mathrm{bb}}$. In this study, 470 and $950 \mathrm{~nm}$ were selected as $\lambda_{1}$ and $\lambda_{2}$ in accordance with previous studies (Sandradewi et al., 2008; Favez et al., 2010; Zotter et al., 2017; Helin et al., 2018; Kalogridis et al., 2018).

In the aethalometer model, one of the largest uncertainties is related to the choice of the $\alpha_{\mathrm{ff}}$ and $\alpha_{\mathrm{bb}}$ values (Sciare et al., 2011; Healy et al., 2017; Zotter et al., 2017; Helin et al., 2018). The site-specific $\alpha$ values are affected by the type of fuel, combustion regime, and mixing state of BC aerosols with non-absorbing materials (Favez et al., 2010; Lack and Langridge, 2013; Garg et al., 2016). All of these factors increase the uncertainty of observation-based source apportionment. In the literature, fixed $\alpha_{\mathrm{ff}}$ and $\alpha_{\mathrm{bb}}$ values were commonly used in source apportionment studies for simplicity (Favez et al., 2010; Herich et al., 2011; Sciare et al., 2011; Harrison et al., 2012; Fuller et al., 2014; Rajesh and Ramachandran, 2017; Zotter et al., 2017; Helin et al., 2018). For example, Sandradewi et al. (2008) suggested that $\alpha_{\mathrm{ff}}$ was 1.1 and $\alpha_{\mathrm{bb}}$ was 1.8-1.9 from the light absorption at 470 and $950 \mathrm{~nm}$. Zotter et al. (2017) suggested the AAE values in the aethalometer model were site- and source-specific and recommended using an $\alpha_{\mathrm{ff}}$ of 0.9 and an $\alpha_{\mathrm{bb}}$ of 1.68 in Switzerland. Based on a comprehensive investigation of previous studies using the aethalometer model (Table S1 in the Supplement), $\alpha_{\mathrm{ff}}$ and $\alpha_{\mathrm{bb}}$ values were most commonly in the ranges of $0.9-1.1$ and 1.7-2.2, respectively. In this work, the empirical value of $\alpha_{\mathrm{ff}}$ and $\alpha_{\mathrm{bb}}$ is adopted as 1.0 and 2.0 following many previous studies (Kirchstetter et al., 2004; Favez et al., 2010; Crippa et al., 2013; Fuller et al., 2014; Crilley et al., 2015; Petit et al., 2017; Vaishya et al., 2017; Xiao et al., 2020). In addition, in order to test the impact of AAE values on the performance of the aethalometer model, a sensitivity analysis with various combinations of AAE pairs was implemented. Except for the base assessment with $\alpha_{\mathrm{ff}}=1.0$ and $\alpha_{\mathrm{bb}}=2.0$, the analysis was conducted by changing the $\alpha_{\mathrm{ff}}$ from 0.9 to 1.1 and the $\alpha_{\mathrm{bb}}$ from 1.7 to 2.2.

\subsection{Potential sources of $\mathrm{BC}_{\mathrm{ff}}$ and $\mathrm{BC}_{\mathrm{bb}}$}

The conditional probability function (CPF) was used to investigate the possible predominant directions of local sources of $\mathrm{BC}_{\mathrm{ff}}$ and $\mathrm{BC}_{\mathrm{bb}}$ relative to wind directions in different seasons (Ashbaugh et al., 1985). The CPF is calculated as

$\mathrm{CPF}_{\Delta \theta}=m_{\Delta \theta} / n_{\Delta \theta}$,

where $n_{\Delta \theta}$ is the total occurrences from wind sector $\Delta \theta$ and $m_{\Delta \theta}$ is occurrences from the same wind sector with the $\mathrm{BC}_{\mathrm{ff}}$ $\left(\mathrm{BC}_{\mathrm{bb}}\right)$ concentration exceeding the threshold criterion. The $\mathrm{CPF}$ analysis was also performed for the ratio of $\mathrm{BC}_{\mathrm{bb}}$ to $\mathrm{BC}\left(\mathrm{BC}_{\mathrm{bb}} / \mathrm{BC}\right)$ to analyze the impact of local sources on the contribution from biomass burning. In this analysis, a threshold criterion of the top $25 \%$ concentration (ratio) was chosen (Deng et al., 2020).

Backward trajectories were simulated with the Hybrid Single Particle Lagrangian Integrated Trajectory model (HYSPLIT) from NOAA/ARL to characterize the regional sources and transport of air masses arriving in Xiamen (Stein et al., 2015). Five-day backward trajectories ending at a height of $500 \mathrm{~m}$ were calculated every hour using the Global Data Assimilation System (GDAS) reanalysis meteorological dataset with a $1^{\circ} \times 1^{\circ}$ latitude-longitude resolution. Hourly trajectory endpoints implying the geographical distribution and the height of the air parcel were derived from the model. Trajectory clusters were then obtained from cluster analysis, which was performed based on the inputs of hourly backward trajectories with the TrajStat plugin of the Meteoinfo (http://www.meteothink.org/, last access: April 2020) software. Four clusters were obtained for each season with the clustering option of angle Euclidean distance. The outflow regimes for air masses to the receptor site with the potential origins were traced with the trajectory clusters.

Potential regional source contributions of $\mathrm{BC}_{\mathrm{ff}}$ and $\mathrm{BC}_{\mathrm{bb}}$ were further identified with the potential source contribution function (PSCF) method on the basis of the backward trajectories. PSCF is a widely adopted tool to identify regional source distributions of air pollutants at a receptor site (Hopke et al., 1995; Bari et al., 2015; Zhang et al., 2017). The study domain is divided into $i \times j$ grid cells, and PSCF values can be calculated as follows:

$\mathrm{PSCF}_{i, j}=m_{i, j} / n_{i, j}$,

where $n_{i, j}$ is the number of endpoints in the $i j$ th grid cell and $m_{i, j}$ is the number of endpoints for the same grid cell that have $\mathrm{BC}_{\mathrm{ff}}\left(\mathrm{BC}_{\mathrm{bb}}\right)$ concentration higher than a criterion. These grid cells with high PSCF values are the maximum probability potential source areas contributing to high $\mathrm{BC}_{\mathrm{ff}}$ $\left(\mathrm{BC}_{\mathrm{bb}}\right)$ mass concentrations at the receptor location. In this work, the top $25 \%$ concentrations were set as the threshold. The study domain covered $10-55^{\circ} \mathrm{N}$ and $80-140^{\circ} \mathrm{E}$, which comprises 10800 grid cells with a size of $0.5^{\circ} \times 0.5^{\circ}$ latitude and longitude. 
To minimize the uncertainty in grid cells with low $n_{i, j}$, an empirical weight function $w_{i, j}$ was multiplied by the PSCF values. $w_{i, j}$ was defined as follows.

$w_{i, j}=\left\{\begin{array}{cc}1.00 & n_{i, j}>3 n_{\text {ave }} \\ 0.70 & 1.5 n_{\text {ave }}<n_{i, j} \leq 3 n_{\text {ave }} \\ 0.42 & n_{\text {ave }}<n_{i, j} \leq 1.5 n_{\text {ave }} \\ 0.05 & n_{i, j} \leq n_{\text {ave }}\end{array}\right\}$

It is difficult for the PSCF method to identify the source intensity and separate strong sources and weak sources. Therefore, the concentration-weighted trajectory (CWT) model was also performed to overcome this limitation. In this method, each grid cell is assigned a weighted concentration by averaging the sample concentrations that have associated trajectories crossing the grid cell (Hsu et al., 2003). The average weighted concentration $C_{i, j}$ in the $i j$ th grid cell was calculated as follows:

$C_{i, j}=\frac{1}{\sum_{l=1}^{M} \tau_{i, j, l}} \sum_{l=1}^{M} C_{l} \tau_{i, j, l}$,

where $M$ is the total number of trajectories, $C_{l}$ is the observed $\mathrm{BC}_{\mathrm{ff}}\left(\mathrm{BC}_{\mathrm{bb}}\right)$ concentration at receptor site on arrival of trajectory $l$ and $\tau_{i, j, l}$ is the number of endpoints in the $i j$ th grid cell of trajectory $l$. In general, the grid cells with high CWT values are high-strength sources. The weighting function $w_{i, j}$ was also adopted in the CWT analysis to reduce the effect of the small values of $n_{i, j}$.

\subsection{Source-oriented modeling}

In this analysis, source apportionment of $\mathrm{BC}$ over Xiamen using an updated source-oriented Community Multiscale Air Quality Modeling System (CMAQ) model for primary particulate matter (CMAQ-PPM) (Hu et al., 2015; Guo et al., 2017) was also implemented in addition to the observationbased source apportionment. The CMAQ-PPM model was updated on the basis of CMAQ v5.0.1, which was developed by the U.S. EPA Atmospheric Science Modeling Division. The photochemical mechanism and aerosol chemistry mechanism adopted in this study were SAPRC-11 and AERO6, respectively. In the source-oriented model, tagged non-reactive PM tracers are used to estimate the source contributions of PPM and its chemical components. The PM tracers are set to undergo the same atmospheric processes as other species. The emissions of the tracers are set to $0.001 \%$ of the PPM emissions from each corresponding source sector and region. This ensures that the tracers will not significantly change the particle mass and size. After scaling up by $10^{5}$, the simulated tracer concentration represents the PPM concentrations from a specific source type/region. The concentrations of the inert chemical components in PPM can be estimated with sourcespecific emission profiles as follows:

$C_{i, j}=A_{i, j} \times \mathrm{PPM}_{i}$, where $C_{i, j}$ is the concentration of the $j$ th component from the $i$ th source, $A_{i, j}$ is the ratio of the $j$ th component in PPM mass from the $i$ th source and $\mathrm{PPM}_{i}$ is the simulated concentration for the $i$ th source. Detailed descriptions of the model can be found in Hu et al. (2015).

The sourced-oriented modeling with tagged tracers is similar to the particulate source apportionment technology (PSAT). However, PSAT does not track the species from different sources directly in each time step. Instead, it allocates the changes in bulk concentrations to different sources after each time step based on the ratio of each source to total emissions. Compared with the source-oriented model, the brute force method (BFM) is more suitable for estimating the change in PM due to proposed emission control measures than for determining the contributions of certain sources because removal of PM emissions could affect the transport, chemistry, deposition and interactions with meteorology, although they are not chemically reactive (Zhang and Ying, 2011). The results simulated with the BFM are different from "source apportionment" since the summation of the contributions of all source categories will not always equal the total concentration. In addition, the BFM needs to repeat chemical transport model simulations multiple times and greatly increases the computational cost.

Regional distributions of $\mathrm{BC}$ from different categories (sectors) as well as the source category (sector) contributions to $\mathrm{BC}$ at the receptor site were determined with the source-oriented CMAQ-PPM model. A $36 \mathrm{~km}$ horizontal resolution domain that covers China and surrounding countries in East Asia (Fig. 1) was applied. There are 18 vertical layers with a surface layer thickness of $35 \mathrm{~m}$ and an overall model height of $20 \mathrm{~km}$. The Weather Research and Forecasting model (WRF) v3.9.1 was utilized to generate meteorology inputs with initial and lateral boundary conditions from NCEP FNL reanalysis data from NCAR, which are available on $1^{\circ} \times 1^{\circ}$ grids continuously for every $6 \mathrm{~h}$ (http://dss.ucar. edu/datasets/ds083.2/, last access: April 2020). There are 29 vertical layers in the WRF domain. The first eight layers of the WRF and CMAQ domains are identical. The outputs of WRF were post-processed by Meteorology-Chemistry Interface Processor (MCIP) v4.2 to the format CMAQ requires. Anthropogenic emissions in China were generated according to the Multi-resolution Emission Inventory for China (MEIC) developed by Tsinghua University (http://www.meicmodel. org, last access: April 2020). Emissions from other countries and regions outside China were generated with the Regional Emission inventory in ASia version 2 (REAS2) (Kurokawa et al., 2013). The fire emissions were derived from the Fire Inventory from NCAR (FINN) based on satellite observations (Wiedinmyer et al., 2011). Anthropogenic emissions were grouped into four sectors, including industrial, power, transportation and residential. Open burning emissions are considered to be the fifth emission sector. Open biomass burning generally refers to open combustion of various biomass materials such as forest vegetation, crop residue and munic- 
ipal solid waste (Permadi and Oanh, 2013). Sources from five sectors were further classified into three categories, such as solid fossil fuel (i.e., coal) combustion, liquid fossil fuel combustion and biomass burning, on the basis of the energy consumption data provided by Wang et al. (2012). The performance of the source-oriented model on $\mathrm{BC}$ was evaluated by all available observations within China in Hu et al. (2015), which found that the model could reproduce the $\mathrm{BC}$ concentrations well, and there was good agreement between the $\mathrm{BC}$ observation and simulation. Spatial distributions of BC concentrations over China are depicted in Fig. S1, suggesting that BC concentration in the western Taiwan Strait region was much lower than that in other urban agglomerations in North China, East-Central China and the Sichuan Basin. However, Xiamen had relatively higher abundance compared to the surrounding areas.

\section{Results and discussion}

\subsection{Light absorption-based source apportionment of BC}

Figure 2 demonstrates the temporal variations in daily mean concentrations of $\mathrm{BC}_{\mathrm{ff}}$ and $\mathrm{BC}_{\mathrm{bb}}$ with the $\mathrm{BC}_{\mathrm{bb}} / \mathrm{BC}$ fraction in Xiamen during the field campaign. The missing data were due to the instrument maintenance. Daily concentrations of $\mathrm{BC}_{\mathrm{ff}}$ and $\mathrm{BC}_{\mathrm{bb}}$ were 445 $9545 \mathrm{ng} \mathrm{m}^{-3}$ (average: $2932 \pm 1444 \mathrm{ng} \mathrm{m}^{-3}$ ) and $334-$ $4031 \mathrm{ng} \mathrm{m}^{-3}\left(1340 \pm 542 \mathrm{ng} \mathrm{m}^{-3}\right)$, respectively. Daily contribution of $\mathrm{BC}_{\mathrm{bb}}$ to total $\mathrm{BC}$ varied significantly in the range of $18.4 \%-58.3 \%$, and the daily $\mathrm{BC}_{\mathrm{ff}} / \mathrm{BC}$ fraction ranged from $41.7 \%$ to $81.6 \%$. The annual average contribution of $\mathrm{BC}_{\mathrm{bb}}$ to $\mathrm{BC}$ was $33.3 \%$, much smaller than that of $\mathrm{BC}_{\mathrm{ff}}$ $(66.7 \%)$, indicating the predominant contribution of fossil fuel combustion in Xiamen. The sensitivity of the aethalometer model was investigated by using different $\alpha_{\mathrm{ff}}$ and $\alpha_{\mathrm{bb}}$ combinations (Fig. 3). The $\mathrm{BC}_{\mathrm{ff}} / \mathrm{BC}$ fraction increased with an increase in $\alpha_{\mathrm{ff}}$ value, and there was even a more rapid increase in that fraction when $\alpha_{\mathrm{bb}}$ increased. Contrarily, the $\mathrm{BC}_{\mathrm{bb}} / \mathrm{BC}$ fraction decreased with the increasing $\alpha_{\mathrm{ff}}$ and $\alpha_{\mathrm{bb}}$ values. In the sensitivity tests, the $\mathrm{BC}_{\mathrm{ff}}$ contributions were in the range from $42 \%\left(\alpha_{\mathrm{ff}}=0.9, \alpha_{\mathrm{bb}}=1.7\right)$ to $79 \%\left(\alpha_{\mathrm{ff}}=\right.$ $\left.1.1, \alpha_{\mathrm{bb}}=2.2\right)$. The sensitivity analysis also indicates that the apportionment results are more sensitive to the changing $\alpha_{\mathrm{bb}}$ values than to $\alpha_{\mathrm{ff}}$ values. For example, keeping the $\alpha_{\mathrm{ff}}$ value at 1.0 , the $\mathrm{BC}_{\mathrm{ff}} / \mathrm{BC}$ increased from $46 \%$ to $75 \%$ for the $\alpha_{\mathrm{bb}}$ value from 1.7 to 2.2. However, a slower increase in the $\mathrm{BC}_{\mathrm{ff}} / \mathrm{BC}$ fraction from $64 \%$ to $72 \%$ was found when the $\alpha_{\mathrm{ff}}$ value changes from 0.9 to 1.1 by fixing the $\alpha_{\mathrm{bb}}$ value at 2.0. It is different from previous studies over Granada in Spain (Titos et al., 2017) and Delhi in India (Dumka et al., 2018), which both found the aethalometer model was more sensitive to $\alpha_{\mathrm{bb}}$ than to $\alpha_{\mathrm{ff}}$.

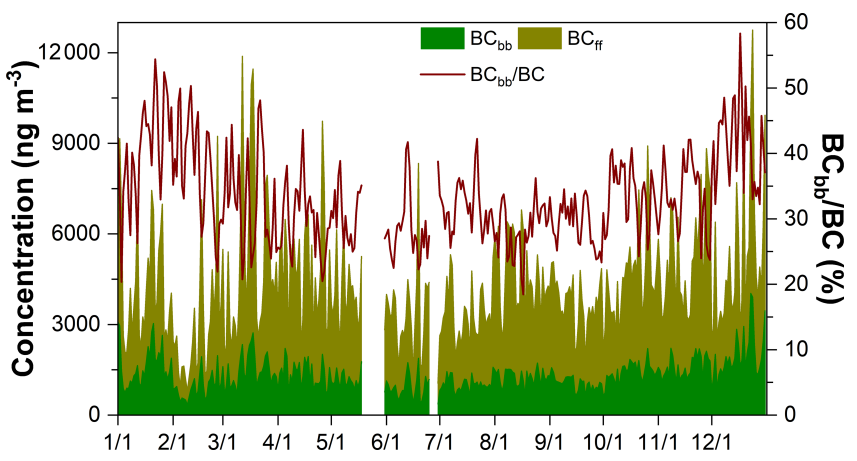

Figure 2. Daily $\mathrm{BC}_{\mathrm{ff}}$ and $\mathrm{BC}_{\mathrm{bb}}$ concentrations and $\mathrm{BC}_{\mathrm{ff}} / \mathrm{BC}$ fraction in Xiamen in 2014.

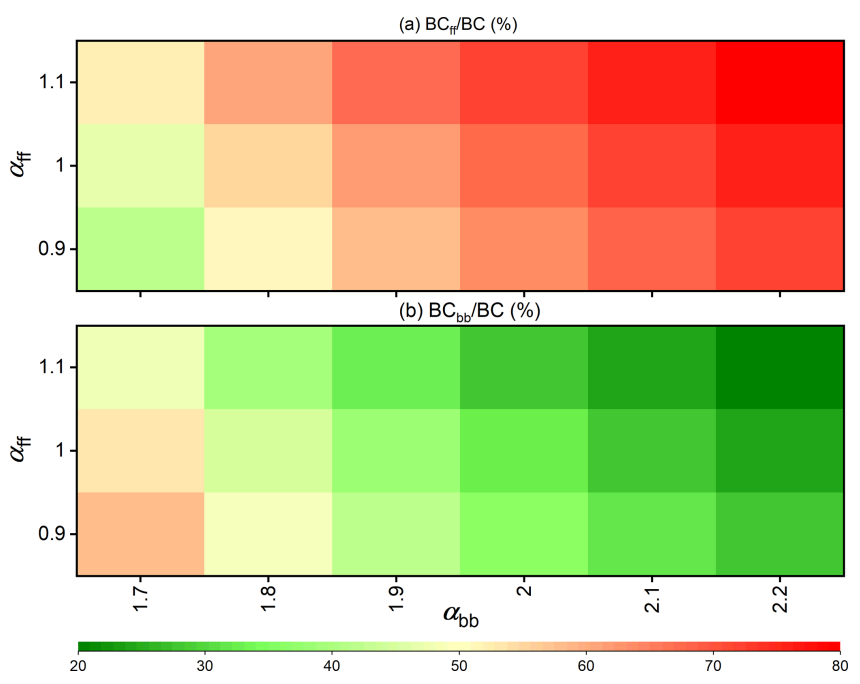

Figure 3. Variations in the (a) $\mathrm{BC}_{\mathrm{ff}} / \mathrm{BC}$ and (b) $\mathrm{BC}_{\mathrm{bb}} / \mathrm{BC}$ fractions with $\alpha_{\mathrm{ff}}$ and $\alpha_{\mathrm{bb}}$.

Source apportionment results under different levels of air pollutants (i.e., $\mathrm{BC}$ and $\mathrm{PM}_{2.5}$ ) in each season were further investigated to understand $\mathrm{BC}$ sources of pollution and clean days (Fig. 4). The data of $\mathrm{PM}_{2.5}$ concentration measured by a Tapered Element Oscillating Microbalance (TEOM) sampler (RP1400, Thermo Fisher Scientific) were from Xiamen Environmental Monitoring Central Station. High-pollutant periods are the days with a daily average concentration higher than the seasonal average plus 1 standard deviation, while low-pollutant periods are the days with a daily average concentration lower than the seasonal average minus 1 standard deviation. Generally, source contributions of BC show obvious variability among different pollution levels in all seasons, and the $\mathrm{BC}_{\mathrm{bb}}$ percentage decreases with the increasing concentrations of $\mathrm{BC}$ and $\mathrm{PM}_{2.5}$. Biomass burning contributed more during low-BC (30.8\%-43.1\%) and low- $\mathrm{PM}_{2.5}$ days $(31.5 \%-40.7 \%)$ compared to high-BC $(24.8 \%-34.4 \%)$ and high-PM 2.5 episodes (26.6\%-36.1\%), implying that emissions from coal combustion and vehicle exhausts are major contributors of particulate pollution in Xiamen. The frac- 


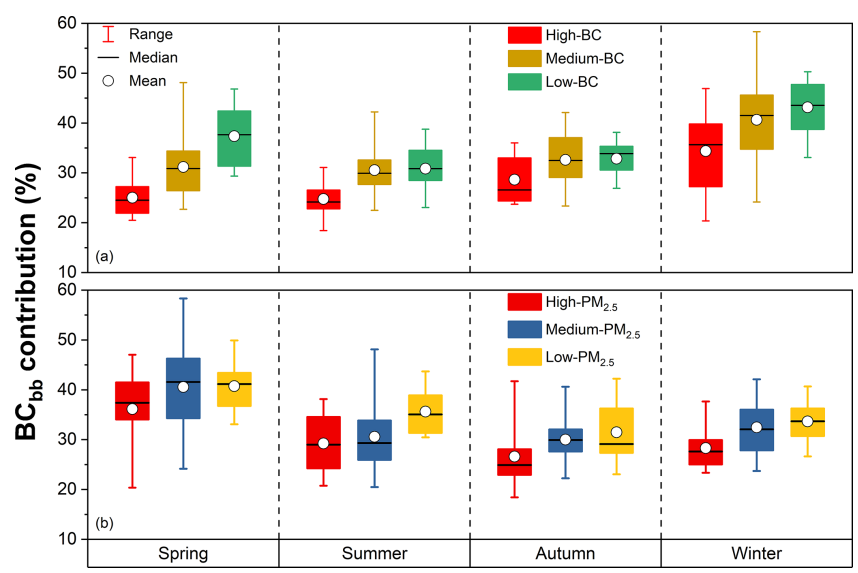

Figure 4. Box plots of $\mathrm{BC}_{\mathrm{bb}}$ contributions with different concentrations of (a) $\mathrm{BC}$ and (b) $\mathrm{PM}_{2.5}$ in different seasons.

tional contribution of fossil fuel to BC in Xiamen derived by the aethalometer method in this work suggests a slighter larger role of fossil fuel compared to that $(61 \%)$ estimated according to the "bottom-up" emission inventories (Chen et al., 2013). However, it was similar to the contribution $(\sim 70 \%)$ in YRD and PRD, which was estimated based on dual carbon isotope constrained source apportionment (Andersson et al., 2015). $\mathrm{BC}_{\mathrm{ff}}$ and $\mathrm{BC}_{\mathrm{bb}}$ percentages in different regions calculated with the aethalometer method were summarized in Table $\mathrm{S} 2$ for comparison. $\mathrm{BC}_{\mathrm{bb}}$ fractions in Xiamen were overall larger than that in Nanjing in China and other sites in India, suggesting that the contribution of biomass burning increases over the relatively clean region due to the weak emissions of traffic and coal combustion.

Figure 5 illustrates the diurnal and monthly cycles of $\mathrm{BC}_{\mathrm{ff}}$ and $\mathrm{BC}_{\mathrm{bb}}$ concentrations as well as the relative contribution of biomass burning $\left(\mathrm{BC}_{\mathrm{bb}} / \mathrm{BC}\right)$ during the measurements. $\mathrm{BC}_{\mathrm{ff}}$ exhibited a pronounced diurnal variation, increasing steadily before dawn with the major morning peak (4427 $\mathrm{n} \mathrm{m}^{-3}$ ) observed around 06:00 in the morning. The high $\mathrm{BC}_{\mathrm{ff}}$ concentrations at the observation site from late night to the early morning ( $\sim 21: 00$ to $08: 00)$ may be ascribed to enhanced traffic emissions from diesel trucks during nighttime and cars during rush hours. The heavy diesel trucks, which are major emission sources of $\mathrm{BC}_{\mathrm{ff}}$, were allowed to enter the city from 22:00 to 07:00. Therefore, $\mathrm{BC}_{\mathrm{ff}}$ decreased during daytime and reached a diurnal minimum of $1950 \mathrm{ng} \mathrm{m}^{-3}$ at 13:00 in the afternoon. $\mathrm{BC}_{\mathrm{bb}}$ exhibited a diurnal trend that was different with $\mathrm{BC}_{\mathrm{ff}}$. The morning peak $\left(1755 \mathrm{ng} \mathrm{m}^{-3}\right)$ at 06:00 was also found for $\mathrm{BC}_{\mathrm{bb}}$. However, $\mathrm{BC}_{\mathrm{bb}}$ concentration kept a steady state rather than increased after 20:00 since $\mathrm{BC}_{\mathrm{bb}}$ was not influenced by traffic-related emission. Clear diurnal variation in contribution of $\mathrm{BC}_{\mathrm{bb}}$ to total $\mathrm{BC}$ was found. The $\mathrm{BC}_{\mathrm{bb}}$ fraction reached its valley of $30.4 \%$ at $08: 00$, increased due to the decrease in traffic emission, and maximized with a ratio of $37.9 \%$ at 19:00 in the evening due to increases in biomass-burning activities. The
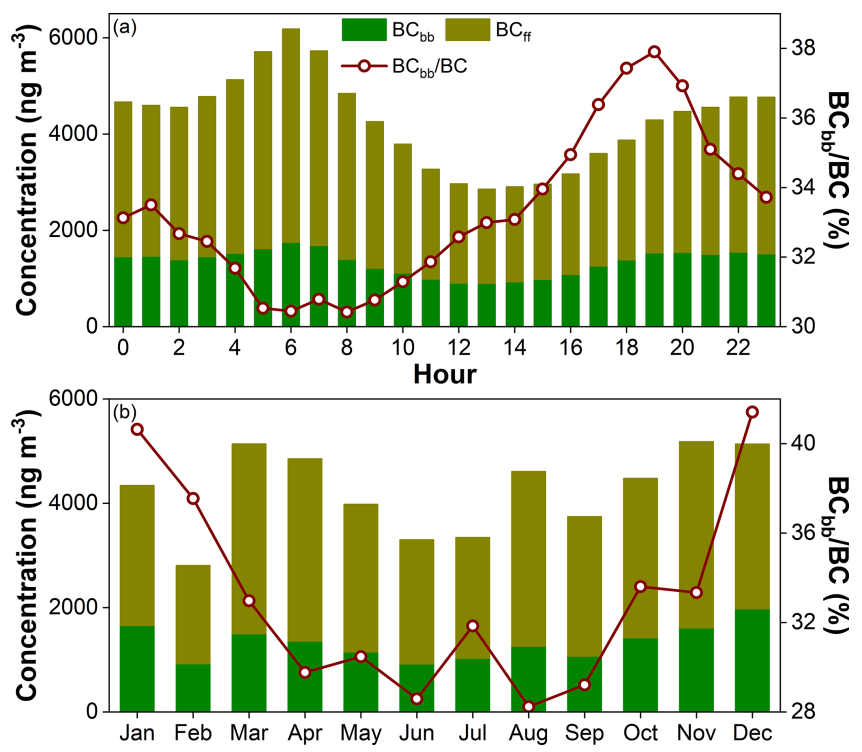

Figure 5. Diurnal and monthly variations in $\mathrm{BC}_{\mathrm{ff}}$ and $\mathrm{BC}_{\mathrm{bb}}$ concentrations with the $\mathrm{BC}_{\mathrm{bb}} / \mathrm{BC}$ fraction.

diurnal cycles of $\mathrm{BC}_{\mathrm{ff}}$ and $\mathrm{BC}_{\mathrm{bb}}$ were affected by not only the $\mathrm{BC}$ emission trend, but also the evolution of the atmospheric boundary layer. According to our previous study on atmospheric boundary layer height in Xiamen (Deng et al., 2020), the boundary layer height was $\sim 3$ times larger in the afternoon than that in the early morning, leading to the better diffusion conditions in the afternoon.

Monthly mean $\mathrm{BC}_{\mathrm{bb}}$ concentration peaked with a value of $1979 \mathrm{ng} \mathrm{m}^{-3}$ in December and reached its valley of $923 \mathrm{ng} \mathrm{m}^{-3}$ in June. The monthly pattern of $\mathrm{BC}_{\mathrm{ff}}$ was similar but a bit different with that of $\mathrm{BC}_{\mathrm{bb}}$. The maximum monthly mean $\mathrm{BC}_{\mathrm{ff}}$ concentration was $3636 \mathrm{ng} \mathrm{m}^{-3}$ in March, while the minimum was $1881 \mathrm{ng} \mathrm{m}^{-3}$ in February. The valley of $\mathrm{BC}_{\mathrm{ff}}$ concentration occurring in February was maybe because of the lack of vehicle (e.g., diesel trucks) emissions around the Spring Festival holiday, which again proves the conjecture in the diurnal pattern of $\mathrm{BC}_{\mathrm{ff}}$. Similar to the seasonal pattern of the absorption Angstrom exponent (Qiu et al., 2019), noticeable seasonal variation in the $\mathrm{BC}_{\mathrm{bb}} / \mathrm{BC}$ fraction was found. Winter (December-February) had the largest $\mathrm{BC}_{\mathrm{bb}}$ contribution (39.9\%), followed by fall (September-November) (32.1\%), spring (March-May) $(31.1 \%)$ and summer (June-August) $(29.6 \%)$. The much larger contributions in winter are possibly due to the enhanced source from open-field biomass and domestic burning in China (He et al., 2011). The higher $\mathrm{BC}_{\mathrm{bb}}$ concentration and contribution lasted from fall to early winter, consistent with a previous emission inventory of biomass burning, which found higher $\mathrm{BC}$ emissions from November to February than other months (He et al., 2011). Unlike $\mathrm{BC}_{\mathrm{ff}}, \mathrm{BC}_{\mathrm{bb}}$ exhibited an increasing trend in July, leading to a relatively large contribution of $\mathrm{BC}_{\mathrm{bb}}$. It might be affected by the long- 
range transport of air pollutants emitted from biomass burning in Southeast Asia under the control of summer monsoon (Qiu et al., 2019). The monthly variation in boundary layer height, which was larger in the warm season and smaller in the cold season, also affected the monthly patterns of $\mathrm{BC}_{\mathrm{ff}}$ and $\mathrm{BC}_{\mathrm{bb}}$ (Deng et al., 2020).

\subsection{Sources and transport pathways of $\mathrm{BC}_{\mathrm{ff}}$ and $\mathrm{BC}_{\mathrm{bb}}$}

The CPF results for the top $25 \%$ thresholds of concentrations of $\mathrm{BC}_{\mathrm{ff}}\left(3797 \mathrm{ng} \mathrm{m}^{-3}\right)$ and $\mathrm{BC}_{\mathrm{bb}}\left(1813 \mathrm{ng} \mathrm{m}^{-3}\right)$ as well as $\mathrm{BC}_{\mathrm{bb}}$ contribution ( $45 \%$ ) over different periods are shown in Fig. 6. In the whole year, high $\mathrm{BC}_{\mathrm{ff}}$ concentrations were mainly associated with winds from west-southwest to northnortheast with wind speed (ws) $<2 \mathrm{~m} \mathrm{~s}^{-1}$ (Fig. 6a). In particular, high $\mathrm{BC}_{\mathrm{ff}}$ concentrations were most remarkably distributed in winds from the northwest at low ws $\left(<\sim 1 \mathrm{~m} \mathrm{~s}^{-1}\right)$ and to a lesser extent from the west and north-northeast at moderate ws $\left(<3 \mathrm{~m} \mathrm{~s}^{-1}\right)$. It implies the impacts of local sources such as the traffic emissions to the northwest of the site within a short distance. The CPF pattern for $\mathrm{BC}_{\mathrm{bb}}$ was similar to but not the same as that of $\mathrm{BC}_{\mathrm{ff}}$ (Fig. 6b). In addition to northwesterly wind with low ws, northeasterly and easterly winds with ws $<5 \mathrm{~m} \mathrm{~s}^{-1}$ were also accompanied by high $\mathrm{BC}_{\mathrm{bb}}$ concentration. Correspondingly, the $\mathrm{CPF}$ plot for the $\mathrm{BC}_{\mathrm{bb}} / \mathrm{BC}$ fraction implies the significant influence of east-northeasterly wind with ws $>2 \mathrm{~m} \mathrm{~s}^{-1}$ on a large contribution of biomass burning (Fig. 6c). In addition, northerly winds with wind speeds $>\sim 4 \mathrm{~m} \mathrm{~s}^{-1}$ were also frequently associated with a large $\mathrm{BC}_{\mathrm{bb}}$ fraction. $\mathrm{CPF}$ patterns presented obvious seasonality. For $\mathrm{BC}_{\mathrm{ff}}$ and $\mathrm{BC}_{\mathrm{bb}}$, the CPF distributions over spring, summer and fall were similar and the high concentrations were mainly associated with northwesterly wind with ws $<2 \mathrm{~ms}^{-1}$. However, in winter, additionally with wind from the northwest, high $\mathrm{BC}_{\mathrm{ff}}$ and $\mathrm{BC}_{\mathrm{bb}}$ concentrations were also frequently associated with wind from the southwest and west with ws $<3 \mathrm{~m} \mathrm{~s}^{-1}$. For the $\mathrm{BC}_{\mathrm{bb}} / \mathrm{BC}$ fraction, large fractions were mainly distributed in northeasterly wind with ws $>4 \mathrm{~m} \mathrm{~s}^{-1}$ and most remarkably distributed in winds from the northeast at high ws $\left(>6 \mathrm{~m} \mathrm{~s}^{-1}\right)$ in spring and summer. In fall, east-northeasterly wind with ws $>3 \mathrm{~m} \mathrm{~s}^{-1}$ was more frequently associated with a large contribution of biomass burning. However, in winter, northerly wind with ws $>4 \mathrm{~m} \mathrm{~s}^{-1}$ and northeasterly wind with ws $>2 \mathrm{~m} \mathrm{~s}^{-1}$ were most remarkably associated with a large $\mathrm{BC}_{\mathrm{bb}}$ percentage.

Seasonal clusters of backward trajectories obtained by the HYSPLIT model with the average $\mathrm{BC}_{\mathrm{bb}}$ contributions are illustrated in Fig. 7. Mean concentrations of $\mathrm{BC}_{\mathrm{ff}}, \mathrm{BC}_{\mathrm{bb}}$ and $\mathrm{BC}$ of each cluster in different seasons are summarized in Table S3. It is clearly shown that origins and transport pathways of air masses arriving in Xiamen exhibited distinct seasonal variations. In summer, air masses were characterized by a predominance of southerly origin. In contrast, in other seasons, air masses from the north had a dominant posi-
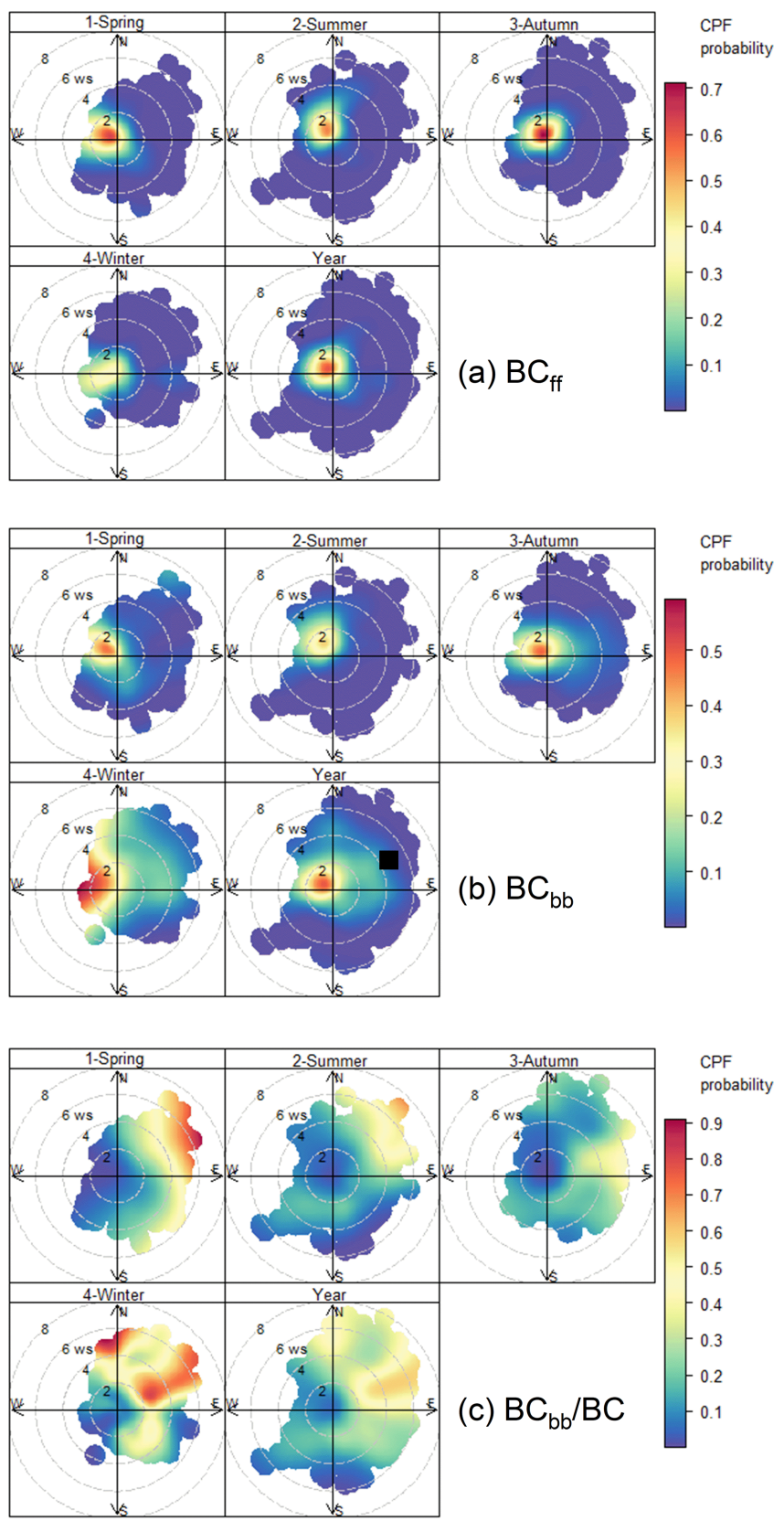

Figure 6. $\mathrm{CPF}$ plots for (a) $\mathrm{BC}_{\mathrm{ff}}$, (b) $\mathrm{BC}_{\mathrm{bb}}$ and (c) $\mathrm{BC}_{\mathrm{bb}}$ contributions in Xiamen in 2014. ws represents wind speed $\left(\mathrm{m} \mathrm{s}^{-1}\right)$.

tion, which was particularly the case in winter. Generally, air masses from the northern inland region such as North China and East-Central China had larger biomass-burning contributions compared to those from seas such as the East China Sea and South China Sea, since there are dense emissions of biomass burning in North and East China, including Hebei, Henan, Shandong and Jiangsu (Huang et al., 2012; Wu et al., 2018). In spring, the eastern cluster (C4) originating from the East China Sea had the lowest $\mathrm{BC}_{\mathrm{bb}}$ fraction $(31 \%)$. However, the northern cluster (C3) originating 
from Siberia and passing through Mongolia and North and East China had a much larger biomass-burning contribution $(42 \%)$ in comparison to the other clusters. In summer, the northeastern coastal cluster (C4) originating from the East China Sea and passing along with East China coast region had a larger biomass-burning contribution (38\%). The northern cluster passing through Jiangsu, Zhejiang and northern Fujian Province also had a relatively higher $\mathrm{BC}_{\mathrm{bb}}$ fraction (35\%). In fall, the northern inland cluster (C3) originating from Siberia and passing through the heavily polluted areas such as the North China Plain and YRD were associated the largest biomass-burning contribution ( $40 \%$ ), followed by the other long-range inland cluster $(\mathrm{C} 2)$ with the $\mathrm{BC}_{\mathrm{bb}}$ fraction of $36 \%$. In winter, similar to spring and fall, the northern cluster from Siberia (C2) had the largest biomass-burning contribution (48\%). Contrarily, the northeastern marine air masses passing along the coastal region had the lowest $\mathrm{BC}_{\mathrm{bb}}$ fraction $(35 \%)$.

Potential sources of $\mathrm{BC}_{\mathrm{ff}}$ and $\mathrm{BC}_{\mathrm{bb}}$ in Xiamen with their contributions were characterized with CWT and PSCF analyses, and the results are presented in Figs. 8 and S2. According to the PSCF and CWT maps of $\mathrm{BC}_{\mathrm{ff}}$ (Figs. S2a and 8a), the strong potential source probabilities for $\mathrm{BC}_{\mathrm{ff}}$ were distributed to the southwest of Xiamen, including southwestern Fujian Province as well as Guangdong Province. Significant potential sources were also located in Hubei, Anhui, Jiangxi and Henan provinces in East-Central China and Hebei and Shandong provinces in North China, again implying the influences of long-range transport on $\mathrm{BC}_{\mathrm{ff}}$ in Xiamen. Southeast Asia with strong regional BC emissions (Permadi et al., 2018) was also indicated as a potential source region. For $\mathrm{BC}_{\mathrm{bb}}$, similar to $\mathrm{BC}_{\mathrm{ff}}$, the PSCF and CWT distributions (Figs. S2b and 8b) show that the exogenous potential sources were mainly distributed in East-Central China, which belonged to the major areas of biomass burning in China (Yan et al., 2006; Huang et al., 2012; Wu et al., 2018). Guangdong Province in South China was also suggested as the source of $\mathrm{BC}_{\mathrm{bb}}$. Unlike $\mathrm{BC}_{\mathrm{ff}}$, the strong potential source probabilities from Southeast Asia to $\mathrm{BC}_{\mathrm{bb}}$ were less significant.

Figures 9 and S3 depict the seasonal CWT and PSCF distributions for $\mathrm{BC}_{\mathrm{ff}}$ and $\mathrm{BC}_{\mathrm{bb}}$. Source distributions of both $\mathrm{BC}_{\mathrm{ff}}$ and $\mathrm{BC}_{\mathrm{bb}}$ in different seasons significantly varied due to the variability in the airflows. In spring, the terrestrial contributions from Guangdong Province and North China to $\mathrm{BC}_{\mathrm{ff}}$ and $\mathrm{BC}_{\mathrm{bb}}$ were significant. In addition, high PSCF and CWT values for summer $\mathrm{BC}_{\mathrm{bb}}$ were also found in North China. In the fall season, similar to spring, high PSCF and CWT values for $\mathrm{BC}_{\mathrm{ff}}$ and $\mathrm{BC}_{\mathrm{bb}}$ were distributed in East-Central China. In winter, the main potential sources of $\mathrm{BC}_{\mathrm{ff}}$ and $\mathrm{BC}_{\mathrm{bb}}$ were also located in East-Central China. The potential sources of $\mathrm{BC}_{\mathrm{bb}}$ in Central China were much stronger in winter than that in other seasons. The East China Sea and South China Sea were also indicated as the potential source areas for $\mathrm{BC}_{\mathrm{ff}}$ and $\mathrm{BC}_{\mathrm{bb}}$ by the PSCF and CWT analysis. However, they should not be real source areas and were identified due to the trailing effect (Lee et al., 2014; Deng et al., 2020).

\subsection{Source-oriented modeling-based source apportionment of $\mathrm{BC}$}

Relative source contributions to BC in Xiamen from different source sectors and fuel catalogs were assessed with the source-oriented CMAQ-PPM model. Figure 10 illustrates the seasonal and annual average contributions of each source sector in Xiamen. Overall, transportation, residential and open burning sectors were the major sources of BC, with annual contributions of $45.3 \%, 30.1 \%$ and $17.6 \%$, respectively. By comparison, power plants and industrial sectors made minor contributions to $\mathrm{BC}$, accounting for $3.4 \%$ and $3.6 \%$, respectively. The transportation sector was the dominant source in all seasons, especially in summer, contributing $36.5 \%-56.6 \%$ to total $\mathrm{BC}$. The residential sector contributing $20.5 \%-37.2 \%$ was the second largest source in all seasons except spring. By contrast, power plants and industrial sectors were minor sources in all seasons, with seasonal contributions of $2.2 \%-6.2 \%$ and $2.8 \%-4.6 \%$, respectively. An obvious seasonal pattern of contribution of open burning was found. In spring and summer, open burning played a vital role by contributing $35.5 \%$ and $17.8 \%$, respectively. However, its relative contributions dramatically decreased to $7.6 \%$ in fall and $7.5 \%$ in winter. Source contributions of the five sectors to BC over China in different periods are depicted in Fig. S4. The remarkable seasonal and spatial variations from open burning are consistent with those derived in a previous study (Hu et al., 2015). In spring, strong open burning in South China might significantly influence BC concentrations in the surrounding regions near the sources, which would contribute to a larger biomass-burning contribution in Xiamen. Intensive open burning in South Asia and Southeast Asia countries (Sharma et al., 2010; Vadrevu et al., 2015; Singh et al., 2020) in spring also affected the biomassburning contribution in Xiamen through long-range transport (Fig. 9).

Seasonal variations in simulated relative contributions of three fuel catalogs (i.e., coal, liquid fossil fuel and biomass) to $\mathrm{BC}$ in Xiamen were demonstrated in Fig. 11. For the entire year, liquid fossil fuel combustion had the largest contribution $(46.5 \%)$, followed by biomass burning $(32.6 \%)$ and coal combustion $(20.9 \%)$. Contributions of different fuel catalogs exhibited distinct seasonality. Seasonal contributions of coal combustion were on the order of winter $(27.8 \%)$ $>$ fall $(23.4 \%)>\operatorname{spring}(15.6 \%)>\operatorname{summer}(14.5 \%)$. For liquid fossil fuel combustion, its largest contribution $(57.5 \%)$ was in summer, and its smallest contribution (37.4\%) was in spring. Seasonal contributions of biomass burning were in the range of $25.7 \%-47.0 \%$, and the average contribution was much larger in spring than in other seasons. Contribution of fossil fuel combustion, which is the sum of liquid fossil 

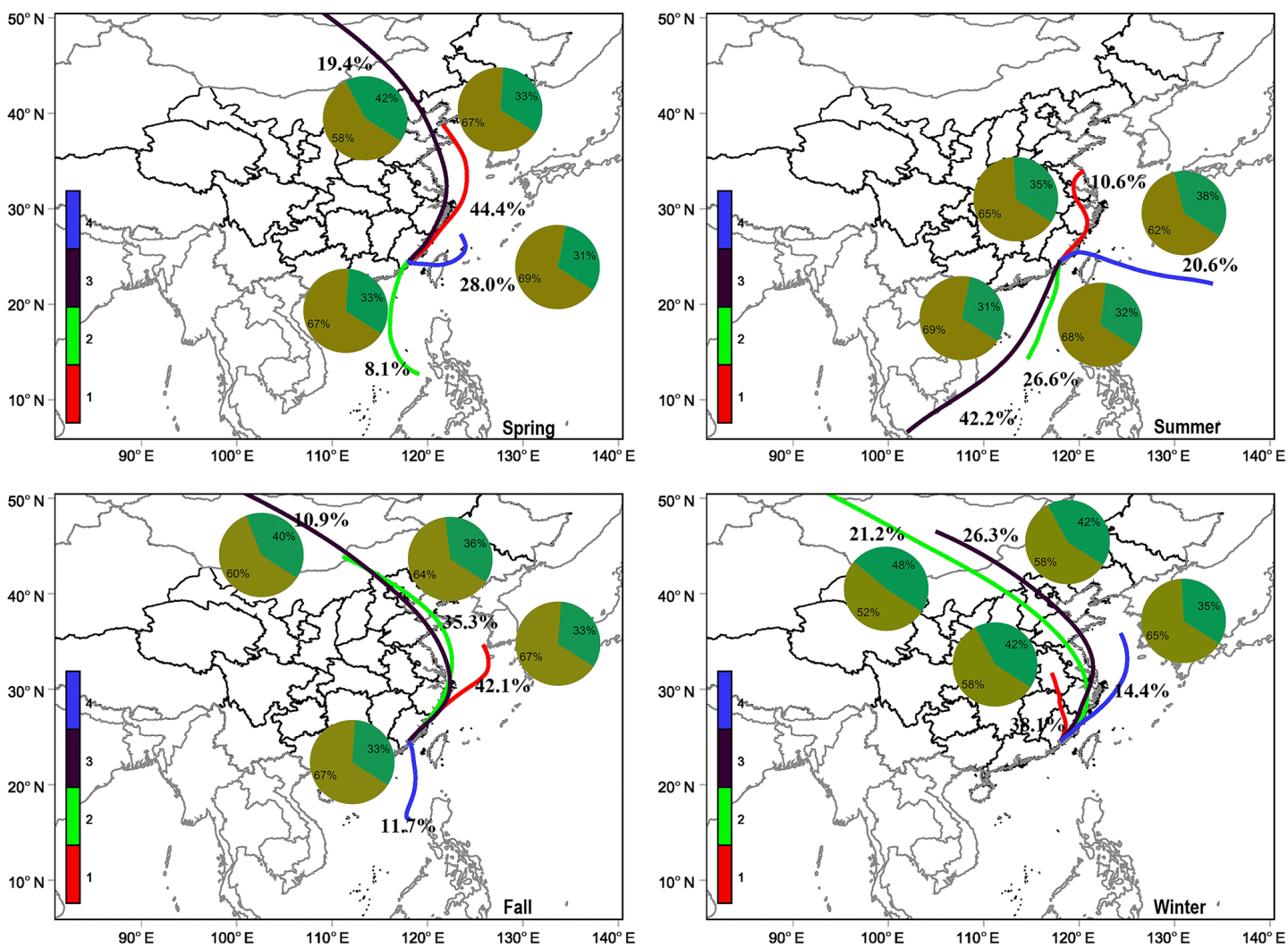

Figure 7. Seasonal cluster mean of $5 \mathrm{~d}$ backward trajectories at $500 \mathrm{~m}$ with the corresponding trajectory percentages and $\mathrm{BC}_{\mathrm{bb}}$ contributions in Xiamen. The pie charts represent relative contributions of $\mathrm{BC}_{\mathrm{ff}}$ (dark yellow) and $\mathrm{BC}_{\mathrm{bb}}$ (olive green). The four-colored legend indicates the four different trajectory clusters. The percentages along the trajectories represent the percentage of each cluster in all trajectories.

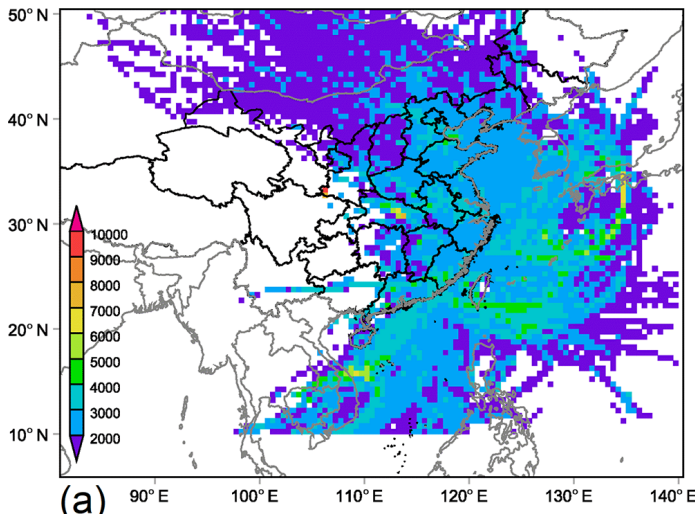

(a)

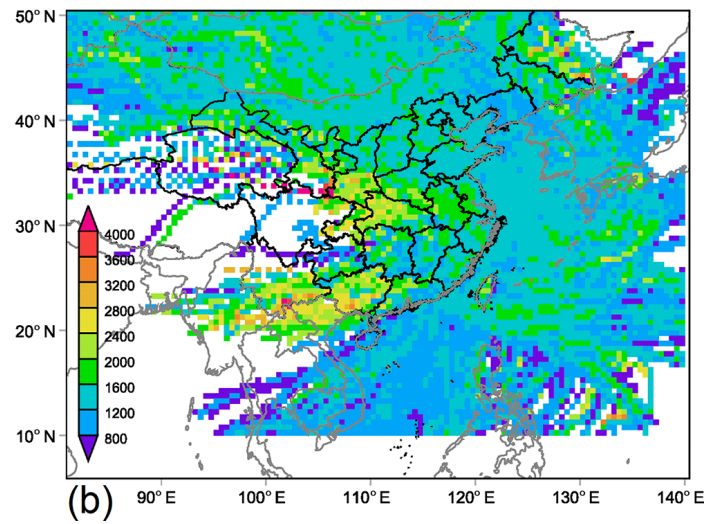

Figure 8. Concentration-weighted trajectory (CWT) maps $\left(\mathrm{ng} \mathrm{m}^{-3}\right)$ for $(\mathbf{a}) \mathrm{BC}_{\mathrm{ff}}$ and $(\mathbf{b}) \mathrm{BC}_{\mathrm{bb}}$ in $\mathrm{Xiamen}$ in 2014.

fuel and coal combustion, followed the order of winter $>$ fall $>$ summer $>$ spring.

The simulated contributions were compared with the source apportionment results estimated according to lightabsorption properties. For the whole year, the annual average relative contributions of $\mathrm{BC}_{\mathrm{ff}}$ and $\mathrm{BC}_{\mathrm{bb}}$ derived by the source-oriented model were $67.4 \%$ and $32.6 \%$, respectively. They were very close to the results (i.e., $66.7 \%$ for $\mathrm{BC}_{\mathrm{ff}}$ and
$33.3 \%$ for $\mathrm{BC}_{\mathrm{bb}}$ ) obtained by the aethalometer method. The overall consistency of the two apportionment methods confirms that the source apportionment results in Xiamen from this study are reasonable and benefit future emission-control strategies. Simulated contributions of $\mathrm{BC}_{\mathrm{ff}}$ and $\mathrm{BC}_{\mathrm{bb}}$ were $72.0 \%$ and $28.0 \%$ in summer and $73.9 \%$ and $26.1 \%$ in fall. The simulated contributions in summer and fall were comparable to those derived by the aethalometer method, and 

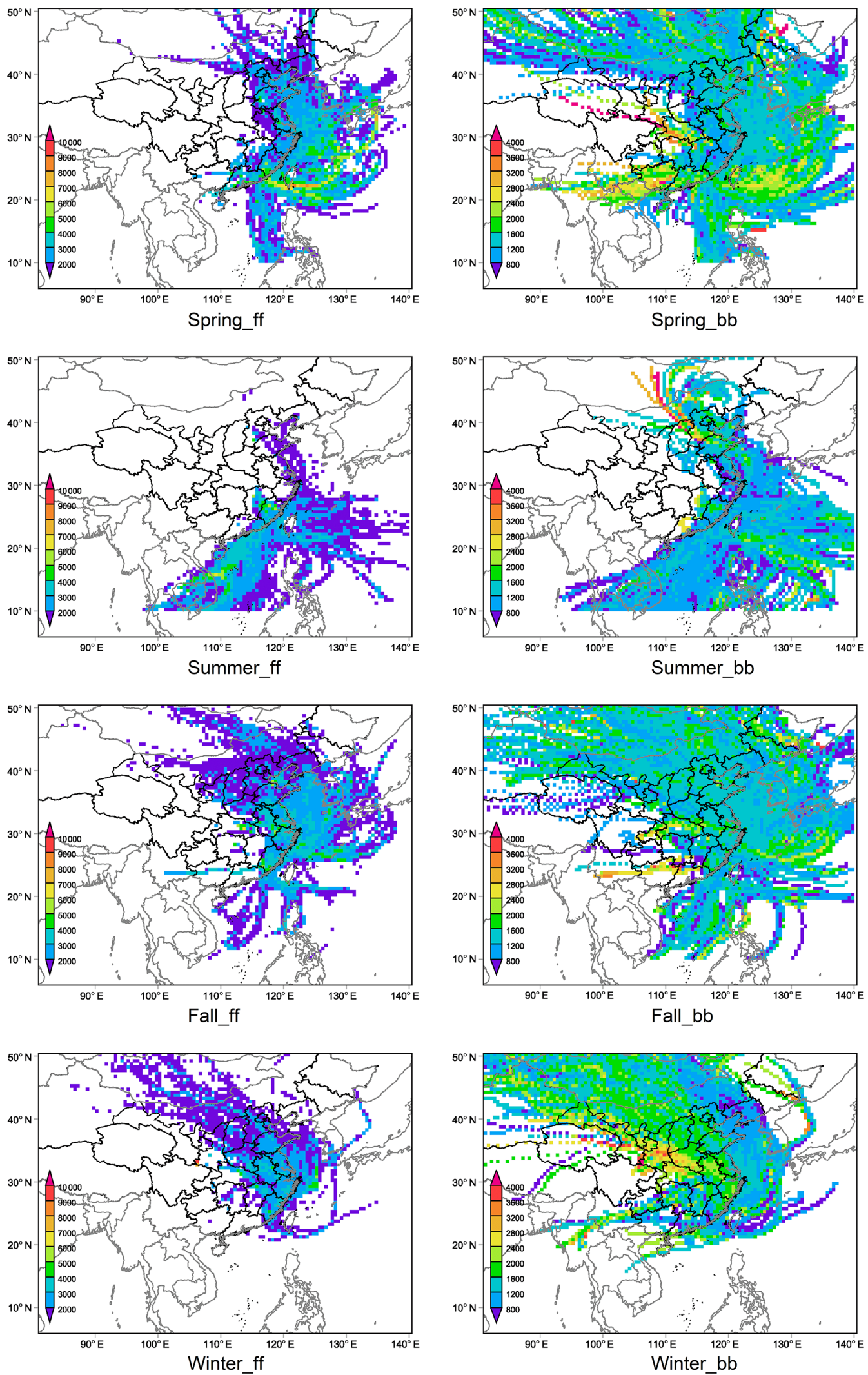

Figure 9. $\mathrm{CWT}$ maps for $\mathrm{BC}_{\mathrm{ff}}$ and $\mathrm{BC}_{\mathrm{bb}}$ in Xiamen for different seasons in 2014. 

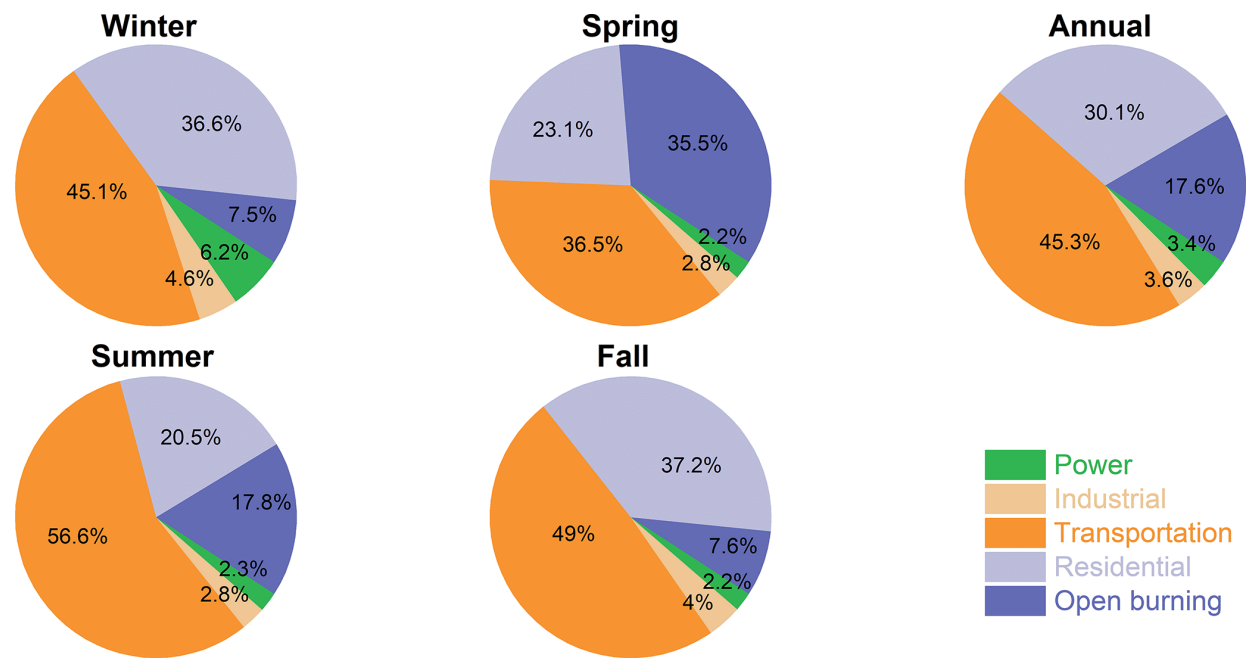

Figure 10. Source contributions to $\mathrm{BC}$ of five source sectors in each period based on the source-oriented model.

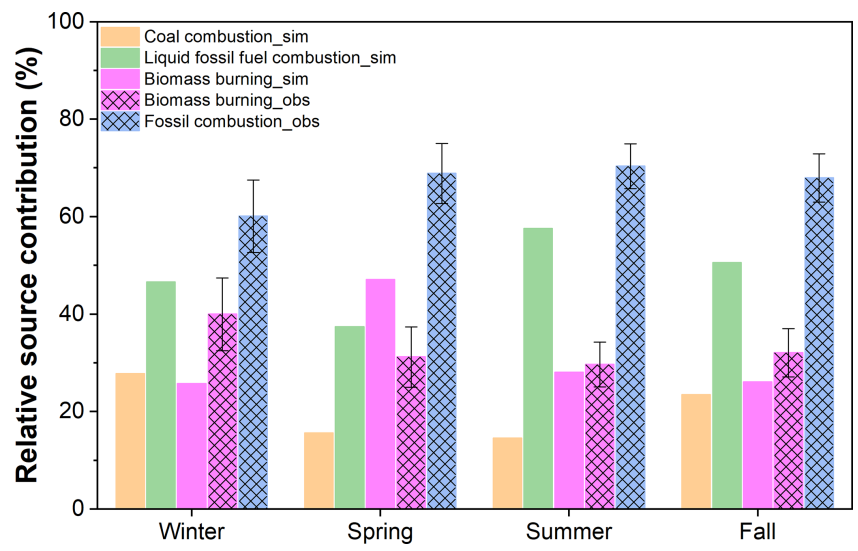

Figure 11. Comparison of seasonal source contribution to $\mathrm{BC}$ between the source-oriented model and the aethalometer method.

the discrepancies between the results from the two methods were $1.7 \%$ in summer and $6.0 \%$ in fall. However, there were considerable differences between the $\mathrm{BC}$ source apportionment results from the aethalometer method and sourceoriented CMAQ model in winter and spring. Relative contributions of $\mathrm{BC}_{\mathrm{ff}}$ and $\mathrm{BC}_{\mathrm{bb}}$ derived by the source-oriented modeling were $74.3 \%$ and $25.7 \%$ in winter and $47.0 \%$ and $53.0 \%$ in spring. Simulated $\mathrm{BC}_{\mathrm{ff}}\left(\mathrm{BC}_{\mathrm{bb}}\right)$ contribution was $14.3 \%$ larger (smaller) in winter and $15.9 \%$ smaller (larger) in spring compared to the observation-based results. Both the uncertainties in the aethalometer method and the emission inventory used in the source-oriented model may lead to the gap between observation-based and model results. For example, due to a lack of auxiliary measurements, the AAE values of $\mathrm{BC}_{\mathrm{ff}}$ and $\mathrm{BC}_{\mathrm{bb}}$ adopted in this study were based on a comprehensive literature review. It would lead to uncertainties in the apportionment results from the aethalometer model, as discussed in Sect. 3.1. On the other hand, the large gap in spring and winter may partly have resulted from the uncertainties in the satellite-based inventory of biomassburning emissions in South Asia and China (Wiedinmyer et al., 2011; Huang et al., 2012; Zhou et al., 2017). In China, some open burning activities such as local-/small-scale open burning and smoldering are important sources of biomassburning $\mathrm{BC}$, which was particularly the case in winter. However, these burning activities are difficult to accurately detect by satellite, leading to considerable uncertainties in biomassburning emissions. In addition, low resolution of simulation could lead to uncertainties in model results. The peak values close to emission sources may not be captured after the dilution of emissions in large grid cells. In future, high resolution is suggested as long as high-resolution emission inventories are available.

\section{Conclusions}

In this study, the observation-based light absorption and source-oriented modeling were combined to reveal the contributions of biomass-burning and fossil fuel combustion to ambient $\mathrm{BC}$ aerosol as well as their temporal variations in a relatively clean region in China. The annual average concentrations of $\mathrm{BC}_{\mathrm{ff}}$ and $\mathrm{BC}_{\mathrm{bb}}$ identified by the aethalometer method with $\alpha_{\mathrm{ff}}=1.0$ and $\alpha_{\mathrm{bb}}=2.0$ were $2932 \pm 1444 \mathrm{ng} \mathrm{m}^{-3}$ and $1340 \pm 542 \mathrm{ng} \mathrm{m}^{-3}$, accounting for $66.7 \%$ and $33.3 \%$ of total $\mathrm{BC}$, respectively. A sensitivity analysis conducted by changing the $\alpha_{\mathrm{ff}}$ and $\alpha_{\mathrm{bb}}$ values suggested that increase in $\alpha_{\mathrm{ff}}$ or $\alpha_{\mathrm{bb}}$ values would lead to increase in $\mathrm{BC}_{\mathrm{ff}}$ against $\mathrm{BC}_{\mathrm{bb}}$, and the aethalometer method was more sensitive to changes in $\alpha_{\mathrm{bb}}$ rather than $\alpha_{\mathrm{ff}}$. For biomass-burning contribution, its highest level occurred in the evening rush hour, while the maximum seasonal value was in winter. East-northeasterly and northerly wind was more likely to result in a large biomass-burning contribu- 
tion. Air masses from the northern inland region including North China and East-Central China had larger biomassburning contributions. Potential sources of $\mathrm{BC}_{\mathrm{ff}}$ and $\mathrm{BC}_{\mathrm{bb}}$ indicate the impact of long-range transport from North and East-Central China and Southeast Asia. Based on the sourceoriented model, the transportation, residential and open burning sectors were the larger contributors to $\mathrm{BC}$ compared to the power and industrial sectors. The largest contribution of liquid fossil fuel combustion to $\mathrm{BC}$ was identified by the source-oriented model, followed by biomass burning and coal combustion. The simulated contributions of $\mathrm{BC}_{\mathrm{ff}}$ and $\mathrm{BC}_{\mathrm{bb}}$ were $67.4 \%$ and $32.6 \%$, respectively, close to the results of the aethalometer method. The simulated contributions in summer and fall were comparable to those derived by the aethalometer method. However, the differences between the two apportionment methods in winter and spring were considerable. The discrepancies between the two source apportionment methods suggest an accurate emission inventory with higher spatiotemporal resolution is required in future studies. Source apportionment of BC in Xiamen from both light absorption observation and source-oriented modeling indicates that the fossil fuel sources should be strictly controlled to limit the $\mathrm{BC}$ pollution. The findings also suggest that it is essential to reduce biomass burning in future pollution management strategies.

Data availability. The data are available upon request from Junjun Deng (dengjunjun@tju.edu.cn).

Supplement. The supplement related to this article is available online at: https://doi.org/10.5194/acp-20-14419-2020-supplement.

Author contributions. JD and $\mathrm{HZ}$ designed the experiments and carried them out. JD and WZ performed the analysis of the observation. $\mathrm{HG}$ and $\mathrm{HZ}$ performed the source-oriented modeling. JZ, $\mathrm{WH}, \mathrm{LW}, \mathrm{XW}$ and PF provided suggestions for data analysis. JD prepared the manuscript with contributions from all the co-authors.

Competing interests. The authors declare that they have no conflict of interest.

Acknowledgements. The authors are grateful for helpful comments from the editor and four anonymous reviewers.

Financial support. This research has been supported by the National Key Research and Development Program of China (grant no. 2019YFA0606801) and the National Natural Science Foundation of China (grant no. 21607148).
Review statement. This paper was edited by Leiming Zhang and reviewed by four anonymous referees.

\section{References}

Andersson, A., Deng, J., Du, K., Zheng, M., Yan, C., Skold, M., and Gustafsson, O.: Regionally-varying combustion sources of the January 2013 severe haze events over Eastern China, Environ. Sci. Technol., 49, 2038-2043, https://doi.org/10.1021/es503855e, 2015.

Ashbaugh, L. L., Malm, W. C., and Sadeh, W. Z.: A residence time probability analysis of sulfur concentrations at Grand Canyon National Park, Atmos. Environ., 19, 1263-1270, https://doi.org/10.1016/0004-6981(85)90256-2, 1985.

Bari, M. A., Kindzierski, W. B., Wallace, L. A., Wheeler, A. J., MacNeill, M., and Heroux, M. E.: Indoor and outdoor levels and sources of submicron particles $\left(\mathrm{PM}_{1}\right)$ at homes in Edmonton, Canada, Environ. Sci. Technol., 49, 6419-6429, https://doi.org/10.1021/acs.est.5b01173, 2015.

Bond, T. C., Doherty, S. J., Fahey, D. W., Forster, P. M., Berntsen, T., DeAngelo, B. J., Flanner, M. G., Ghan, S., Kärcher, B., Koch, D., Kinne, S., Kondo, Y., Quinn, P. K., Sarofim, M. C., Schultz, M. G., Schulz, M., Venkataraman, C., Zhang, H., Zhang, S., Bellouin, N., Guttikunda, S. K., Hopke, P. K., Jacobson, M. Z., Kaiser, J. W., Klimont, Z., Lohmann, U., Schwarz, J. P., Shindell, D., Storelvmo, T., Warren, S. G., and Zender, C. S.: Bounding the role of black carbon in the climate system: A scientific assessment, J. Geophys. Res.-Atmos., 118, 5380-5552, https://doi.org/10.1002/jgrd.50171, 2013.

Cao, J., Tie, X., Xu, B., Zhao, Z., Zhu, C., Li, G., and Liu, S.: Measuring and modeling black carbon (BC) contamination in the SE Tibetan Plateau, J. Atmos. Chem., 67, 45, https://doi.org/10.1007/s10874-011-9202-5, 2010.

Chen, B., Andersson, A., Lee, M., Kirillova, E. N., Xiao, Q., Krusa, M., Shi, M., Hu, K., Lu, Z., Streets, D. G., Du, K., and Gustafsson, O.: Source Forensics of Black Carbon Aerosols from China, Environ. Sci. Technol., 47, 9102-9108, https://doi.org/10.1021/es401599r, 2013.

Chen, H. M., Zhuang, B. L., Liu, J., Li, S., Wang, T. J., Xie, X. D., Xie, M., Li, M. M., and Zhao, M.: Regional climate responses in East Asia to the black carbon aerosol direct effects from India and China in summer, J. Climate, 33, 9783-9800, https://doi.org/10.1175/JCLI-D-19-0706.1, 2020.

Cheng, Y., Engling, G., He, K.-B., Duan, F.-K., Ma, Y.-L., Du, Z.Y., Liu, J.-M., Zheng, M., and Weber, R. J.: Biomass burning contribution to Beijing aerosol, Atmos. Chem. Phys., 13, 77657781, https://doi.org/10.5194/acp-13-7765-2013, 2013.

Colicino, E., Wilson, A., Frisardi, M. C., Prada, D., Power, M. C., Hoxha, M., Dioni, L., Spiro, A., Vokonas, P. S., Weisskopf, M G., Schwartz, J. D., and Baccarelli, A. A.: Telomere length, longterm black carbon exposure, and cognitive function in a cohort of older men: The VA normative aging study, Environ. Health Persp., 125, 76-81, https://doi.org/10.1289/EHP241, 2017.

Crilley, L. R., Bloss, W. J., Yin, J., Beddows, D. C. S., Harrison, R. M., Allan, J. D., Young, D. E., Flynn, M., Williams, P., Zotter, P., Prevot, A. S. H., Heal, M. R., Barlow, J. F., Halios, C. H., Lee, J. D., Szidat, S., and Mohr, C.: Sources and contributions of wood smoke during winter in London: assessing local 
and regional influences, Atmos. Chem. Phys., 15, 3149-3171, https://doi.org/10.5194/acp-15-3149-2015, 2015.

Crippa, M., DeCarlo, P. F., Slowik, J. G., Mohr, C., Heringa, M. F., Chirico, R., Poulain, L., Freutel, F., Sciare, J., Cozic, J., Di Marco, C. F., Elsasser, M., Nicolas, J. B., Marchand, N., Abidi, E., Wiedensohler, A., Drewnick, F., Schneider, J., Borrmann, S., Nemitz, E., Zimmermann, R., Jaffrezo, J.-L., Prévôt, A. S. H., and Baltensperger, U.: Wintertime aerosol chemical composition and source apportionment of the organic fraction in the metropolitan area of Paris, Atmos. Chem. Phys., 13, 961-981, https://doi.org/10.5194/acp-13-961-2013, 2013.

Deng, J., Zhang, Y., Hong, Y., Xu, L., Chen, Y., Du, W., and Chen, J.: Optical properties of $\mathrm{PM}_{2.5}$ and the impacts of chemical compositions in the coastal city $\mathrm{Xi}$ amen in China, Sci. Total Environ., 557-558, 665-675, https://doi.org/10.1016/j.scitotenv.2016.03.143, 2016.

Deng, J., Zhao, W., Wang, X., Wu, L., Hu, W., Ren, L., and Fu, P.: Black carbon in Xiamen, China: temporal variations, transport pathways and impacts of synoptic circulation, Chemosphere, 241, 125133, https://doi.org/10.1016/j.chemosphere.2019.125133, 2020.

Ding, A. J., Fu, C. B., Yang, X. Q., Sun, J. N., Petäjä, T., Kerminen, V.-M., Wang, T., Xie, Y., Herrmann, E., Zheng, L. F., Nie, W., Liu, Q., Wei, X. L., and Kulmala, M.: Intense atmospheric pollution modifies weather: a case of mixed biomass burning with fossil fuel combustion pollution in eastern China, Atmos. Chem. Phys., 13, 10545-10554, https://doi.org/10.5194/acp-13-105452013, 2013.

Ding, A. J., Huang, X., Nie, W., Sun, J. N., Kerminen, V. M., Petaja, T., Su, H., Cheng, Y. F., Yang, X. Q., Wang, M. H., Chi, X. G., Wang, J. P., Virkkula, A., Guo, W. D., Yuan, J., Wang, S. Y., Zhang, R. J., Wu, Y. F., Song, Y., Zhu, T., Zilitinkevich, S., and Kulmala, M.: Enhanced haze pollution by black carbon in megacities in China, Geophys. Res. Lett., 43, 2873-2879, https://doi.org/10.1002/2016GL067745, 2016.

Dumka, U. C., Kaskaoutis, D. G., Tiwari, S., Safai, P. D., Attri, S. D., Soni, V. K., Singh, N., and Mihalopoulos, N.: Assessment of biomass burning and fossil fuel contribution to black carbon concentrations in Delhi during winter, Atmos. Environ., 194, 93109, https://doi.org/10.1016/j.atmosenv.2018.09.033, 2018.

Fan, J., Rosenfeld, D., Yang, Y., Zhao, C., Leung, L. R., and Li, Z.: Substantial contribution of anthropogenic air pollution to catastrophic floods in Southwest China, Geophys. Res. Lett., 43, 2873-2879, https://doi.org/10.1002/2015GL064479, 2015.

Favez, O., El Haddad, I., Piot, C., Boréave, A., Abidi, E., Marchand, N., Jaffrezo, J.-L., Besombes, J.-L., Personnaz, M.-B., Sciare, J., Wortham, H., George, C., and D'Anna, B.: Intercomparison of source apportionment models for the estimation of wood burning aerosols during wintertime in an Alpine city (Grenoble, France), Atmos. Chem. Phys., 10, 5295-5314, https://doi.org/10.5194/acp-10-5295-2010, 2010.

Fuller, G. W., Tremper, A. H., Baker, T. D., Yttri, K. E., and Butterfield, D.: Contribution of wood burning to $\mathrm{PM}_{10}$ in London, Atmos. Environ., 87, 87-94, https://doi.org/10.1016/j.atmosenv.2013.12.037, 2014.

Ganguly, D., Jayaraman, A., Gadhavi, H., and Rajesh, T. A.: Features in wavelength dependence of aerosol absorption observed over central India, Geophys. Res. Lett., 32, L13821, https://doi.org/10.1029/2005GL023023, 2005.
Garg, S., Chandra, B. P., Sinha, V., Sarda-Esteve, R., Gros, V., and Sinha, B.: Limitation of the use of the absorption angstrom exponent for source apportionment of equivalent black carbon: a case study from the north west indo-gangetic plain, Environ. Sci. Technol., 50, 814-824, http://https://doi.org/10.1021/acs.est.5b03868, 2016.

Guo, H., Kota, S. H., Sahu, S. K., Hu, J., Ying, Q., Gao, A., and Zhang, H.: Source apportionment of $\mathrm{PM}_{2.5}$ in North India using source-oriented air quality models, Environ. Pollut., 231, 426436, https://doi.org/10.1016/j.envpol.2017.08.016, 2017.

Gustafsson, O., Krusa, M., Zencak, Z., Sheesley, R. J., Granat, L., Engstrom, E., Praveen, P. S., Rao, P. S. P., Leck, C., and Rodhe, H.: Brown Clouds over South Asia: Biomass or Fossil Fuel Combustion?, Science, 323, 495-498, https://doi.org/10.1126/science.1164857, 2009

Hansen, A. D. A., Rosen, H., and Novakov, T.: The aethalometer - An instrument for the real-time measurements of optical absorption by aerosol particles, Sci. Total Environ., 36, 191-196, https://doi.org/10.1016/0048-9697(84)90265-1, 1984.

Harrison, R. M., Beddows, D. C. S., Hu, L., and Yin, J.: Comparison of methods for evaluation of wood smoke and estimation of UK ambient concentrations, Atmos. Chem. Phys., 12, 82718283, https://doi.org/10.5194/acp-12-8271-2012, 2012.

He, M., Zheng, J., Yin, S., and Zhang, Y.: Trends, temporal and spatial characteristics, and uncertainties in biomass burning emissions in the Pearl River Delta, China, Atmos. Environ., 45, 40514059, https://doi.org/10.1016/j.atmosenv.2011.04.016, 2011.

Healy, R. M., Sofowote, U., Su, Y., Debosz, J., Noble, M., Jeong, C. H., Wang, J. M., Hilker, N., Evans, G. J., Doerksen, G., Jones, K., and Munoz, A.: Ambient measurements and source apportionment of fossil fuel and biomass burning black carbon in Ontario, Atmos. Environ., 161, 34-47, https://doi.org/10.1016/j.atmosenv.2017.04.034, 2017.

Helin, A., Niemi, J. V., Virkkula, A., Pirjola, L., Teinila, K., Backman, J., Aurela, M., Saarikoski, S., Ronkko, T., Asmi, E., and Timonen, H.: Characteristics and source apportionment of black carbon in the Helsinki metropolitan area, Finland, Atmos. Environ., 190, 87-98, https://doi.org/10.1016/j.atmosenv.2018.07.022, 2018.

Herich, H., Hueglin, C., and Buchmann, B.: A 2.5 year's source apportionment study of black carbon from wood burning and fossil fuel combustion at urban and rural sites in Switzerland, Atmos. Meas. Tech., 4, 1409-1420, https://doi.org/10.5194/amt-4-14092011, 2011.

Hopke, P. K., Barrie, L. A., Li, S. M., Cheng, M. D., Li, C., and Xie, Y.: Possible sources and preferred pathways for biogenic and non-sea salt sulfur for the high Arctic, J. Geophys. Res.Atmos., 100, 16595-16603, https://doi.org/10.1029/95JD01712, 1995.

Hsu, Y. K., Holsen, T. M., and Hopke, P. K.: Comparison of hybrid receptor models to locate PCB sources in Chicago, Atmos. Environ., 37, 545-562, https://doi.org/10.1016/S13522310(02)00886-5, 2003.

Hu, J., Wu, L., Zheng, B., Zhang, Q., He, K., Chang, Q., Li, X., Yang, F., Ying, Q., and Zhang, H.: Source contributions and regional transport of primary particulate matter in China, Environ. Pollut., 207, 31-42, https://doi.org/10.1016/j.envpol.2015.08.037, 2015. 
Huang, X., Li, M., Li, J., and Song, Y.: A high-resolution emission inventory of crop burning in fields in China based on MODIS Thermal anomalies/fire products, Atmos. Environ., 50, 9-15, https://doi.org/10.1016/j.atmosenv.2012.01.017, 2012.

Huang, X., Ding, A., Liu, L., Liu, Q., Ding, K., Niu, X., Nie, W., Xu, Z., Chi, X., Wang, M., Sun, J., Guo, W., and Fu, C.: Effects of aerosol-radiation interaction on precipitation during biomassburning season in East China, Atmos. Chem. Phys., 16, 1006310082, https://doi.org/10.5194/acp-16-10063-2016, 2016.

Jacobson, M. Z.: Control of fossil-fuel particulate black carbon and organic matter, possibly the most effective method of slowing global warming, J. Geophys. Res.-Atmos., 107, 4410-4431, https://doi.org/10.1029/2001JD001376, 2002.

Janssen, N. A., Hoek, G., Simic-Lawson, M., Fischer, P., van Bree, L., ten Brink, H., Keuken, M., Atkinson, R. W., Anderson, H. R., Brunekreef, B., and Casses, F. R.: Black Carbon as an Additional Indicator of the Adverse Health Effects of Airborne Particles Compared with $\mathrm{PM}_{10}$ and $\mathrm{PM}_{2.5}$, Environ. Health Persp., 119, 1691-1699, https://doi.org/10.1289/ehp.1003369, 2011.

Jing, A., Zhu, B., Wang, H., Yu, X., An, J., and Kang, H.: Source apportionment of black carbon in different seasons in the northern suburb of Nanjing, China, Atmos. Environ., 201, 190-200, https://doi.org/10.1016/j.atmosenv.2018.12.060, 2019.

Kalogridis, A.-C., Vratolis, S., Liakakou, E., Gerasopoulos, E., Mihalopoulos, N., and Eleftheriadis, K.: Assessment of wood burning versus fossil fuel contribution to wintertime black carbon and carbon monoxide concentrations in Athens, Greece, Atmos. Chem. Phys., 18, 10219-10236, https://doi.org/10.5194/acp-1810219-2018, 2018.

Kant, Y., Shaik, D. S., Mitra, D., Chandola, H. C., Babu, S. S., and Chauhan, P.: Black carbon aerosol quantification over north-west Himalayas: Seasonal heterogeneity, source apportionment and radiative forcing, Environ. Pollut., 257, 113446, https://doi.org/10.1016/j.envpol.2019.113446, 2020

Kim, H., Kang, S. M., Hwang, Y. T., and Yang, Y. M.: Sensitivity of the Climate Response to the Altitude of Black Carbon in the Northern Subtropics in an Aquaplanet GCM, J. Climate, 16, 6351-6359, https://doi.org/10.1175/JCLI-D-15-0037.1, 2015.

Kirchstetter, T. W., Novakov, T., and Hobbs, P. V.: Evidence that the spectral dependence of light absorption by aerosols is affected by organic carbon, J. Geophys. Res.-Atmos., 109, D21208, https://doi.org/10.1029/2004JD004999, 2004.

Kleeman, M. J., Ying, Q., Lu, J., Mysliwiec, M. J., Griffin, R. J., Chen, J. J., and Clegg, S.: Source apportionment of secondary organic aerosol during a severe photochemical smog episode, Atmos. Environ., 41, 576-591, https://doi.org/10.1016/j.atmosenv.2006.08.042, 2007.

Kurokawa, J., Ohara, T., Morikawa, T., Hanayama, S., JanssensMaenhout, G., Fukui, T., Kawashima, K., and Akimoto, H.: Emissions of air pollutants and greenhouse gases over Asian regions during 2000-2008: Regional Emission inventory in ASia (REAS) version 2, Atmos. Chem. Phys., 13, 11019-11058, https://doi.org/10.5194/acp-13-11019-2013, 2013.

Lack, D. A. and Langridge, J. M.: On the attribution of black and brown carbon light absorption using the Ångström exponent, Atmos. Chem. Phys., 13, 10535-10543, https://doi.org/10.5194/acp-13-10535-2013, 2013.

Lee, G., Kim, P., Han, Y., Holsen, T., and Lee, S.: Tracing sources of total gaseous mercury to Yongheung Is- land off the coast of Korea, Atmosphere-Basel, 5, 273-291, http://https://doi.org/10.3390/atmos5020273, 2014.

Li, K., Liao, H., Mao, Y., and Ridley, D. A.: Source sector and region contributions to concentration and direct radiative forcing of black carbon in China, Atmos. Environ., 124, 351-366, https://doi.org/10.1016/j.atmosenv.2015.06.014, 2016.

Li, N., He, Q., Tie, X., Cao, J., Liu, S., Wang, Q., Li, G., Huang, R., and Zhang, Q.: Quantifying sources of elemental carbon over the Guanzhong Basin of China: A consistent network of measurements and WRF-Chem modeling, Environ. Pollut., 214, 86-93, https://doi.org/10.1016/j.envpol.2016.03.046, 2016.

Liu, D., Allan, J. D., Young, D. E., Coe, H., Beddows, D., Fleming, Z. L., Flynn, M. J., Gallagher, M. W., Harrison, R. M., Lee, J., Prevot, A. S. H., Taylor, J. W., Yin, J., Williams, P. I., and Zotter, P.: Size distribution, mixing state and source apportionment of black carbon aerosol in London during wintertime, Atmos. Chem. Phys., 14, 10061-10084, https://doi.org/10.5194/acp-1410061-2014, 2014.

Lou, S., Yang, Y., Wang, H., Smith, S. J., Qian, Y., and Rasch, P. J.: Black Carbon Amplifies Haze Over the North China Plain by Weakening the East Asian Winter Monsoon, Geophys. Res. Lett., 46, 452-460, https://doi.org/10.1029/2018GL080941, 2019.

Martinsson, Martinsson, J., Abdul Azeem, H., Sporre, M. K., Bergström, R., Ahlberg, E., Öström, E., Kristensson, A., Swietlicki, E., and Eriksson Stenström, K.: Carbonaceous aerosol source apportionment using the Aethalometer model - evaluation by radiocarbon and levoglucosan analysis at a rural background site in southern Sweden, Atmos. Chem. Phys., 17, 4265-4281, https://doi.org/10.5194/acp-17-4265-2017, 2017.

Mbengue, S., Serfozo, N., Schwarz, J., Zikova, N., Smejkalova, A. H., and Holoubek, I.: Characterization of Equivalent Black Carbon at a regional background site in Central Europe: Variability and source apportionment, Environ. Pollut., 260, 113771, https://doi.org/10.1016/j.envpol.2019.113771, 2020

Menon, S., Hansen, J., Nazarenko, L., and Luo, Y.: Climate effects of black carbon aerosols in China and India, Science, 297, 22502253, https://doi.org/10.1126/science.1075159, 2002.

Mousavi, A., Sowlat, M. H., Hasheminassab, S., Polidori, A., and Sioutas, C.: Spatio-temporal trends and source apportionment of fossil fuel and biomass burning black carbon (BC) in the Los Angeles Basin, Sci. Total Environ., 640-641, 1231-1240, https://doi.org/10.1016/j.scitotenv.2018.06.022, 2018.

Mousavi, A., Sowlat, M. H., Lovett, C., Rauber, M., Szidat, S., Boffi, R., Borgini, A., Marco, C. D., Ruprecht, A. A., and Sioutas, C.: Source apportionment of black carbon (BC) from fossil fuel and biomass burning in metropolitan Milan, Italy, Atmos. Environ., 203, 252-261, https://doi.org/10.1016/j.atmosenv.2019.02.009, 2019.

Peng, J., Hu, M., Guo, S., Du, Z., Zheng, J., Shang, D., Zamora, M. L., Zeng, L., Shao, M., Wu, Y. S., Zheng, J., Wang, Y., Glen, C. R., Collins, D. R., Molina, M. J., and Zhang, R: Markedly enhanced absorption and direct radiative forcing of black carbon under polluted urban environments, P. Natl. Acad. Sci. USA, 113 4266-4271, https://doi.org/10.1073/pnas.1602310113, 2016.

Permadi, D. A., and Kim Oanh, N. T.: Assessment of biomass open burning emissions in Indonesia and potential climate forcing impact, Atmos. Environ., 78, 250-258, https://doi.org/10.1016/j.atmosenv.2012.10.016, 2013. 
Permadi, D. A., Kim Oanh, N. T., and Vautard, R.: Integrated emission inventory and modeling to assess distribution of particulate matter mass and black carbon composition in Southeast Asia, Atmos. Chem. Phys., 18, 2725-2747, https://doi.org/10.5194/acp18-2725-2018, 2018.

Petit, J.-E., Amodeo, T., Meleux, F., Bessagnet, B., Menut, L., Grenier, D., Pellan, Y., Ockler, A., Rocq, B., Gros, V., Sciare, J., and Favez, O.: Characterising an intense PM pollution episode in March 2015 in France from multi-site approach and near real time data: Climatology, variabilities, geographical origins and model evaluation, Atmos. Environ., 155, 68-84, https://doi.org/10.1016/j.atmosenv.2017.02.012, 2017.

Qian, Y., Wang, H., Zhang, R., Flanner, M. G., and Rasch, P. J.: A sensitivity study on modeling black carbon in snow and its radiative forcing over the Arctic and Northern China, Environ. Res. Lett., 9, 064001, https://doi.org/10.1088/1748-9326/9/6/064001, 2014.

Qiu, Y., Wu, X., Zhang, Y., Xu, L., Hong Y., Chen, J., Chen, X., and Deng, J.: Aerosol light absorption in a coastal city in Southeast China: temporal variations and implications for brown carbon, J. Environ. Sci., 80, 257-266, https://doi.org/10.1016/j.jes.2019.01.002, 2019.

Rajesh, T. A. and Ramachandran, S.: Characteristics and source apportionment of black carbon aerosols over an urban site, Environ. Sci. Pollu. Res., 24, 8411-8424, https://doi.org/10.1007/s11356017-8453-3, 2017.

Ramanathan, V. and Carmichael, G.: Global and regional climate changes due to black carbon, Nat. Geosci., 1, 221-227, https://doi.org/10.1038/ngeo156, 2008.

Rehman, I. H., Ahmed, T., Praveen, P. S., Kar, A., and Ramanathan, V.: Black carbon emissions from biomass and fossil fuels in rural India, Atmos. Chem. Phys., 11, 7289-7299, https://doi.org/10.5194/acp-11-7289-2011, 2011.

Saide, P. E., Spak, S. N., Pierce, R. B., Otkin, J. A., Schaack, T. K., Heidinger, A. K., daSilva, A. M., Kacenelenbogen, M., Redemann, J., and Carmichael, G. R.: Central American biomass burning smoke can increase tornado severity in the U.S., Geophys. Res. Lett., 42, 956-965, https://doi.org/10.1002/2014GL062826, 2015.

Sandradewi, J., Prevot, A. S. H., Szidat, S., Perron, N., Alfarra, M. R., Lanz, V. A., Weingartner, E., and Baltensperger, U.: Using aerosol light absorption measurements for the quantitative determination of wood burning and traffic emission contributions to particulate matter, Environ. Sci. Technol., 42, 3316-3323, https://doi.org/10.1021/es702253m, 2008.

Sciare, J., d'Argouges, O., Sarda-Esteve, R., Caimoz, C., Dolgorouky, C., Bonnaire, N., Favez, O., Bonsang, B., and Gros, V.: Large contribution of water-insoluble secondary organic aerosols in the region of Paris (France) during wintertime, J. Geophys. Res., 116, D22203, https://doi.org/10.1029/2011JD015756, 2011

Sharma, A. R., Kharol, S. K., Badarinath, K. V. S., and Singh, D.: Impact of agriculture crop residue burning on atmospheric aerosol loading - A study over Punjab State, India, Ann. Geophys., 28, 367-379, https://doi.org/10.5194/angeo-28-367-2010, 2010.

Singh, P., Sarawade, P., and Adhikary, B.: Carbonaceous Aerosol from Open Burning and its Impact on Regional Weather in South Asia, Aerosol Air Qual. Res., 20, 419-431, https://doi.org/10.4209/aaqr.2019.03.0146, 2020.

Stein, A. F., Draxler, R. R., Rolph, G. D., Stunder, B. J. B., Cohen, M. D., and Ngan, F.: NOAA's HYSPLIT atmospheric transport and dispersion modeling system, B. Am. Meteorol. Soc., 96, 2059-2077, https://doi.org/10.1175/BAMS-D-14$00110.1,2015$.

Titos, G., del Águila, A., Cazorla, A., Lyamani, H., CasqueroVera, J. A., Colombi, C., Cuccia, E., Gianelle, V., Močnik, G., Alastuey, A., Olmo, F. J., and Alados-Arboledas, L.: Spatial and temporal variability of carbonaceous aerosols: assessing the impact of biomass burning in the urban environment, Sci. Total Environ. 578, 613-625, https://doi.org/10.1016/j.scitotenv.2016.11.007, 2017.

Vadrevu, K. P., Lasko, K., Giglio, L., and Justice, C.: Vegetation fires, absorbing aerosols and smoke plume characteristics in diverse biomass burning regions of Asia, Environ. Res. Lett., 10, 105003, https://doi.org/10.1088/1748-9326/10/10/105003, 2015.

Vaishya, A., Singh, P., Rastogi, S., and Babu, S. S.: Aerosol black carbon quantification in the central Indo-Gangetic Plain: Seasonal heterogeneity and source apportionment, Atmos. Res., 185, 13-21, https://doi.org/10.1016/j.atmosres.2016.10.001, 2017.

Venkataraman, C., Habib, G., Eiguren-Fernandez, A., Miguel, A. H., and Friedlander, S. K.: Residential biofuels in south Asia: carbonaceous aerosol emissions and climate impacts, Science, 307, 1454-1456, https://doi.org/10.1126/science.1104359, 2005.

Virkkula, A., Mäkelä, T., Hillamo, R., Yli-Tuomi, T., Hirsikko, A., Hämeri, K., and Koponen, I. K.: A simple procedure for correcting loading effects of Aethalometer data, J. Air Waste Manage., 57, 10, 1214-1222, https://doi.org/10.3155/10473289.57.10.1214, 2007.

Wang, Q. Y., Huang, R.-J., Cao, J. J., Tie, X. X., Ni, H. Y., Zhou, Y. Q., Han, Y. M., Hu, T. F., Zhu, C. S., Feng, T., Li, N., and Li, J. D.: Black carbon aerosol in winter northeastern Qinghai-Tibetan Plateau, China: the source, mixing state and optical property, Atmos. Chem. Phys., 15, 13059-13069, https://doi.org/10.5194/acp-15-13059-2015, 2015.

Wang, R., Tao, S., Wang, W., Liu, J., Shen, H., Shen, G., Wang, B., Liu, X., Li, W., Huang, Y., Zhang, Y., Lu, Y., Chen, H., Chen, Y., Wang, C., Zhu, D., Wang, X., Li, B., Liu, W., and Ma, J.: Black carbon emissions in China from 1949 to 2050, Environ. Sci. Technol., 46, 7595-7603, https://doi.org/10.1021/es3003684, 2012.

Wang, Z., Huang, X., and Ding, A.: Dome effect of black carbon and its key influencing factors: a one-dimensional modelling study, Atmos. Chem. Phys., 18, 2821-2834, https://doi.org/10.5194/acp-18-2821-2018, 2018.

Watson, J. G.: Visibility: science and regulation, J. Air Waste Manage., 52, 628-713, https://doi.org/10.1080/10473289.2002.10470813, 2002.

Wiedinmyer, C., Akagi, S. K., Yokelson, R. J., Emmons, L. K., AlSaadi, J. A., Orlando, J. J., and Soja, A. J.: The Fire INventory from NCAR (FINN): a high resolution global model to estimate the emissions from open burning, Geosci. Model Dev., 4, 625641, https://doi.org/10.5194/gmd-4-625-2011, 2011.

Winiger, P., Barrett, T. E., Sheesley, R. J., Huang, L., Sharma, S., Barrie, L. A., Yttri, K. E., Evangeliou, N., Eckhardt, S., Stohl, A., Klimont, Z., Heyes, C., Semiletov, I. P., Dudarev, O. V., Charkin, A., Shakhova, N., Holmstrand, H., Andersson, A., and 
Gustafsson, O.: Source apportionment of circum-Arctic atmospheric black carbon from isotopes and modeling, Sci. Adv., 5, eaau8052, https://doi.org/10.1126/sciadv.aau8052, 2019.

Wu, D., Wu, C., Liao, B., Chen, H., Wu, M., Li, F., Tan, H., Deng, T., Li, H., Jiang, D., and Yu, J. Z.: Black carbon over the South China Sea and in various continental locations in South China, Atmos. Chem. Phys., 13, 12257-12270, https://doi.org/10.5194/acp-13-12257-2013, 2013.

Wu, J., Kong, S., Wu, F., Cheng, Y., Zheng, S., Yan, Q., Zheng, H., Yang, G., Zheng, M., Liu, D., Zhao, D., and Qi, S.: Estimating the open biomass burning emissions in central and eastern China from 2003 to 2015 based on satellite observation, Atmos. Chem. Phys., 18, 11623-11646, https://doi.org/10.5194/acp-18-116232018, 2018.

Yan, X., Ohara, T., and Akimoto, H.: Bottom-up estimate of biomass burning in mainland China, Atmos. Environ., 40, 52625273, https://doi.org/10.1016/j.atmosenv.2006.04.040, 2006.

Xiao, S., Yu, X., Zhu, B., Kumar, K. R., Li, M., and Li, L.: Characterization and source apportionment of black carbon aerosol in the Nanjing Jiangbei New Area based on two years of measurements from Aethalometer, J. Aerosol. Sci., 139, 105461, https://doi.org/10.1016/j.jaerosci.2019.105461, 2020.

Yang, Y., Wang, H., Smith, S. J., Ma, P.-L., and Rasch, P. J.: Source attribution of black carbon and its direct radiative forcing in China, Atmos. Chem. Phys., 17, 4319-4336, https://doi.org/10.5194/acp-17-4319-2017, 2017.

Ying, Q., Lu, J., Kaduwela, A., and Kleeman, M.: Modeling air quality during the California REGIONAL $\mathrm{PM}_{10} / \mathrm{PM}_{2.5}$ Air Quality Study (CPRAQS) using the UCD/CIT Source Oriented Air Quality Model - Part II. Regional source apportionment of primary airborne particulate matter, Atmos. Environ., 42, 89678978, https://doi.org/10.1016/j.atmosenv.2008.05.065, 2008.

Yu, K., Xing, Z., Huang, X., Deng, J., Andersson, A., Fang, W., Gustafsson, O., Zhou, J., and Du, K.: Characterizing and sourcing ambient $\mathrm{PM}_{2.5}$ over key emission regions in China III: Carbon isotope based source apportionment of black carbon, Atmos. Environ., 177, 12-17, https://doi.org/10.1016/j.atmosenv.2018.01.009, 2018.

Zhang, H. and Ying, Q.: Contributions of local and regional sources of $\mathrm{NOx}$ to ozone concentrations in Southeast Texas, Atmos. Environ., 45, 2877-2887, https://doi.org/10.1016/j.atmosenv.2011.02.047, 2011.

Zhang, H., DeNero, S. P., Joe, D. K., Lee, H.-H., Chen, S.-H., Michalakes, J., and Kleeman, M. J.: Development of a source oriented version of the WRF/Chem model and its application to the California regional $\mathrm{PM}_{10} / \mathrm{PM}_{2.5}$ air quality study, Atmos. Chem. Phys., 14, 485-503, https://doi.org/10.5194/acp-14-4852014, 2014.
Zhang, Y., Zhang, H., Deng, J., Du, W., Hong, Y., Xu, L., Qiu, Y., Hong, Z., Wu, X., Ma, Q., and Yao, J.: Source regions and transport pathways of $\mathrm{PM}_{2.5}$ at a regional background site in East China, Atmos. Environ., 167, 202-211, https://doi.org/10.1016/j.atmosenv.2017.08.031, 2017.

Zhang, Y., Li, M., Cheng, Y., Geng, G., Hong, C., Li, H., Li, X., Tong, D., Wu, N., Zhang, X., Zheng, B., Zheng, Y., Bo, Y., $\mathrm{Su}, \mathrm{H}$., and Zhang, Q.: Modeling the aging process of black carbon during atmospheric transport using a new approach: a case study in Beijing, Atmos. Chem. Phys., 19, 9663-9680, https://doi.org/10.5194/acp-19-9663-2019, 2019.

Zheng, H., Kong, S., Wu, F., Cheng, Y., Niu, Z., Zheng, S., Yang, G., Yao, L., Yan, Q., Wu, J., Zheng, M., Chen, N., Xu, K., Yan, Y., Liu, D., Zhao, D., Zhao, T., Bai, Y., Li, S., and Qi, S.: Intra-regional transport of black carbon between the south edge of the North China Plain and central China during winter haze episodes, Atmos. Chem. Phys., 19, 4499-4516, https://doi.org/10.5194/acp-19-4499-2019, 2019.

Zhou, Y., Xing, X., Lang, J., Chen, D., Cheng, S., Wei, L., Wei, X., and Liu, C.: A comprehensive biomass burning emission inventory with high spatial and temporal resolution in China, Atmos. Chem. Phys., 17, 2839-2864, https://doi.org/10.5194/acp17-2839-2017, 2017.

Zhuang, B. L., Chen, H. M., Li, S., Wang, T. J., Liu, J., Zhang, L. J., Liu, H. N., Xie, M., Chen, P. L., Li, M. M., and Zhao, M.: The direct effects of black carbon aerosols from different source sectors in East Asia in summer, Clim. Dynam., 53, 5293-5310, https://doi.org/10.1007/s00382-019-04863-5, 2019.

Zhuang, B. L., Li, S., Wang, T. J., Liu, J., Chen, P. L., Chen, H. M., Li, M. M, and Xie, M.: Interaction between the black carbon aerosol warming effect and East Asian monsoon using RegCM4, J. Climate, 31, 9367-9388, https://doi.org/10.1175/JCLI-D-170767.1, 2018.

Zotter, P., Herich, H., Gysel, M., El-Haddad, I., Zhang, Y., Močnik, G., Hüglin, C., Baltensperger, U., Szidat, S., and Prévôt, A. S. H.: Evaluation of the absorption Angström exponents for traffic and wood burning in the Aethalometer-based source apportionment using radiocarbon measurements of ambient aerosol, Atmos. Chem. Phys., 17, 4229-4249, https://doi.org/10.5194/acp17-4229-2017, 2017. 